\title{
Sedentism, Settlements, and Radiocarbon Dates of Neolithic Korea
}

\author{
$\boldsymbol{\Delta} \cdot \boldsymbol{\Delta} \cdot \boldsymbol{\Delta}$ \\ SUNG-MO AHN, JANGSUK KIM, AND JAEHOON HWANG
}

\section{INTRODUCTION}

SEDENTARY SETTLEMENTS APPEARED IN THE EARLy FOURTH MILLENNIUM B.C. in centralwestern Korea and in the late fourth millennium B.c. in southern Korea. Small-scale millet cultivation introduced from northern China seems to have been adopted by Neolithic hunter-gatherers almost simultaneously. However, the adoption of millet cultivation did not lead immediately to transitioning to a farming economy: the appearance of a farming economy was long delayed until the beginning of the Bronze Age ("Mumun" in Korean) when agricultural villages established rice fields and the so-called "Mumun crop assemblage," including rice, naked bread wheat, six-rowed barley, soybean, and azuki bean along with foxtail millet and broomcorn millet (Ahn 2010 : 93). While Korean archaeologists agree that the farming economy began in the Bronze Age, there are two conflicting models regarding the role of Neolithic millet cultivation in the development of the Bronze Age farming economy. The "continuity model" suggests that the emergence of a farming economy was a consequence of increasing sedentism brought about by earlier millet cultivation, so millet cultivation practiced during the Neolithic played a significant role in the transition to the Bronze Age. The "discontinuity model" instead suggests that the degree of sedentism during the late Neolithic was very low and that the development of a Bronze Age farming economy heavily depended on rice and had little to do with previous millet cultivation.

In a recent review of the Korean Neolithic, Shin, Rhee, and Aikens (2012) follow the continuity model in seeing the transition to the Bronze Age as a gradual process. They argue that "by Late Chulmun Neolithic times, certain local elite family lineages had become empowered with sufficient resources and social leverage to recruit and direct community labor toward creating the ditches and paddy fields essential to the enormously productive wet-rice agriculture that in succeeding Mumun times fueled the emergence of Korea's Bronze Age" (Shin et al. 2012:69). Song (2009) and Lee (2011) also advocate the continuity model. They argue that the transition to the Bronze Age farming economy was a consequence of deepening dependence on crop 
cultivation during the Neolithic. In contrast, the discontinuity model suggests that although settlements with small-scale cultivation appeared during the Early or Middle Neolithic, the population returned to mobile or semisedentary lifeways during the last several hundred years of the Neolithic. Bronze Age agricultural society was instigated by the advent of migrant farmers from the north (Ahn 2006; Kim 2002, 2003, 2011; Lim 2006, 2009).

For the continuity model to be correct, sedentism should have increased or at least been sustained until the last phase of the Neolithic. This could be verified by analyzing temporal variation in sedentary settlements or houses. In this article, we test the continuity model by looking at variations in sedentism over time. This is done by quantitatively analyzing sedentary settlements and their relationships with millet cultivation. Although various indices have been used for measuring sedentism (Kelly 1992, 1995:148-152), in this article we regard the existence of pit houses in settlements as a criterion of sedentism. The significant labor put into pit house construction (such as digging into the ground, leveling the floor, constructing a hearth, erecting poles, and raising the roof) can be assumed to be related to some degree of sedentism or at least semisedentism. In examining temporal changes in the degree of sedentism during the Neolithic, we use both a relative chronology (pottery dating) and absolute radiocarbon dates.

\section{NEOLITHIC CHRONOLOGY OF KOREA}

An economy dependent on maritime resources and flat-bottomed pottery with raised or impressed design first appeared along the eastern and southern coast of the Korean Peninsula during the 6th-5th millennium B.C. These people maintained interactions with the Russian Maritime culture and Kyushu on the Japanese archipelago. In the early fourth millennium B.C., a sedentary hunter-gather economy with conical bottomed Chulmun pottery, called the Chulmun Culture by archaeologists, appeared in central-western Korea. This culture adopted small-scale millet cultivation through interacting with people in the Liaoning area in China. The Chulmun Culture spread to southern Korea along with millet cultivation during the late fourth millennium B.C.

Chronologies of the Korean Neolithic vary because of geographical variations in pottery and different archaeological methods for developing chronologies. Table 1 summarizes the chronologies favored by different scholars. Based on excavations of Dongsam-dong (Sample 1974) and Suga-ri (Pusan Museum 1981) shell middens, five phases have been established and generally accepted for southern Korea: Initial (appliqué decorated pottery); Early (Youngseondong-type pottery with impressed designs); Middle (Sugari-1-type pottery with classic incised design); Late (Sugari-2-type and Bonggyeri-type pottery with degenerated or reduced design); and Final (Yulri-type or double-mouth pottery). This chronological scheme also applies to the central-eastern coast, where, with minor modifications, the typological sequence of pottery is similar to that of southern Korea. Because many sites with multiple cultural layers have been excavated in southern Korea and typological sequences using pottery have been intensively studied, these chronological divisions can be used as the basis for chronologies of other areas of Neolithic Korea. Middle phase pottery, spread from the classic Chulmun Culture of central-western Korea into southern Korea, connects the chronologies of the two areas. Calibrated radiocarbon dates indicate that the Initial phase 
Table i. Chronologies of the Central-Western and Southern Korean Neolithic

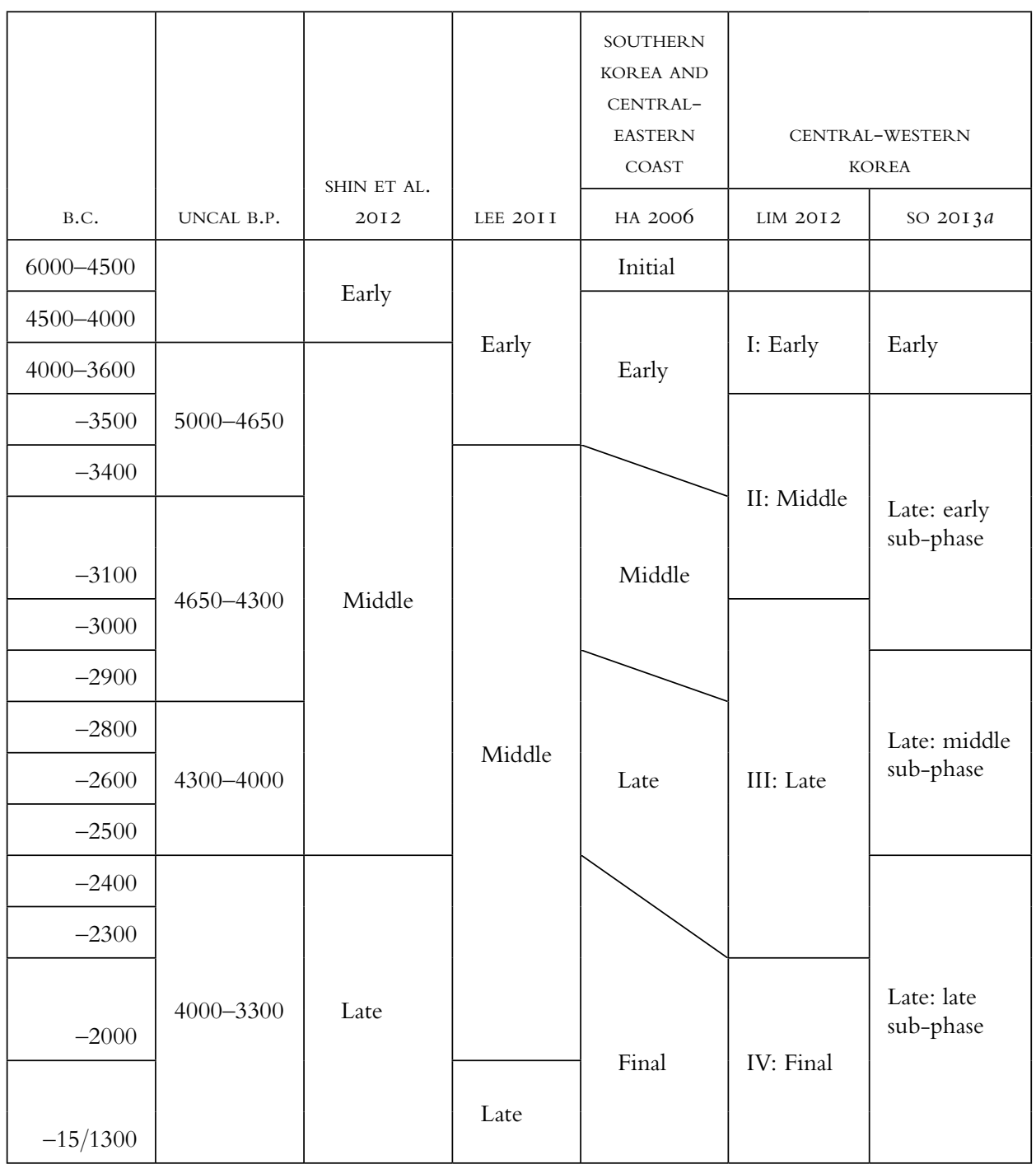

dates to c. 6000-4500 B.C.; Early phase to 4500-3500 B.C.; Middle phase to 3500-2900 B.C.; Late phase to 2900-2300 B.C.; and Final phase to 2300-1500 B.C. (Ha 2006).

Where the stylistic sequence of pottery differs in the central-western Korean Neolithic from that of southern Korea, it is usually divided into Early, Middle, and Late phases (Shin et al. 2012:73, figure 2). Adding a fourth Final phase to the traditional three-phase chronology, Lim (2012) suggests the Early phase dates to 4000-3600 B.C.; Middle to 3600-3100 B.C.; Late to 3100-2300 B.C.; and the Final phase to 2300-1500 B.C. Pointing out that variations in pottery design after around 3500 B.C. reflect local variations rather than temporal variations, some archaeologists prefer a two-phase division into Early and Late phases (Kim 2002). Based mainly on radiocarbon dates, So $(2013 a, 2013 b)$ recently divided the central-western Neolithic into Phase I 
(4500-3600 в.с.) and Phase II (post-3600 в.с.), and subdivided the latter into three sub-phases: Early (3600-3000 B.C.), Middle (3000-2600 в.с.), and Late (2600-1500 B.C.). The duration of the three sub-phases in Phase II correspond roughly to the Middle, Late, and Final phases of the southern Korean Neolithic.

In discussing the Korean Neolithic in this article, we adopt Ha's (2006) five-phase division (i.e., Initial, Early, Middle, Late, and Final) for southern Korea and the central-eastern coast, and the four-phase division proposed by Lim (2012) for centralwestern Korea. Although the divisions differ (e.g., no Initial phase in central-western Korea) due to geographical differences in pottery sequences, we consider the two schemes well matched by cross-dating and they are the most widely cited chronologies in studies of the Korean Neolithic.

\section{SMALL-SCALE CULTIVATION IN THE NEOLITHIC}

Crop remains from Korean Neolithic sites are compiled in Table 2. Analyzing different proxies (i.e., phytoliths, pollen, carbonized and waterlogged seeds, pottery impressions) yield somewhat different stories of the emergence of agriculture in Korea. We use plant macroremains with direct AMS (Accelerator Mass Spectrometry) dates and impressions on pottery sherds with secure dates as reliable indicators of cultivation or agriculture. Many crop grain remains have been recovered through flotation during the last decade; most have been identified as foxtail and broomcorn millets (Lee 2003, 2011; Lee, Crawford, et al. 2011). AMS dates of millets have been reported from the Middle phase of both the central and southern regions of Korea, indicating that millets were cultivated at least as early as the late fourth millennium B.C. in both areas (Lee 2011). Regardless of their status as domesticates, azuki beans, and soybeans were also obtained from the late phase of the early third millennium B.C. Lee argues that azuki and soy beans were first introduced as weeds into millet fields, then were exploited as foods, and finally began to be cultivated starting in the third millennium B.C. (Lee 2013; Lee, Crawford, et al. 2011).

There is controversy over whether rice, wheat, and barley were cultivated during the Neolithic, however (Ahn 2013; Bae et al. 2013). The occurrence and quantity of charred grains of these crops are scarce and direct AMS dates for the grains have not yet been reported. In addition, recent use of SEM (Scanning Electron Microscopy) to investigate plant impressions on pottery is generating new interpretations of the first appearance of millet and rice cultivation in Korea (Obata 2013).

\section{Millet Cultivation}

Reliable evidence of millet with AMS dates indicates millet cultivation appeared in the Middle Neolithic around c. 3500 B.C. Foxtail and broomcorn millets have been identified from flotation samples (Lee 2011) and impressions on pottery (Nakayama 2014) from Middle Neolithic sites. Millet remains have not yet been recovered from Early Neolithic sites in central-western Korea, probably because of lack of archaeobotanical research in the area. However, the central-western area shares close cultural similarities to an Early phase Jitap-ri site in the northwestern area, where a large quantity of millet grains has been recovered. This suggests that millet cultivation may also have been practiced in central-western Korea in the Early Neolithic (Ahn 2013). 
Table 2. Cultivated* Plant Remains from Korean Neolithic Sites

\begin{tabular}{|c|c|c|c|c|c|}
\hline REGION & SITE & FEATURE & PHASE & METHOD & $\begin{array}{l}\text { CROPS AND LEGUMES } \\
\text { (NUMBER OF GRAINS/FEATURES) }\end{array}$ \\
\hline \multirow[t]{3}{*}{ NW } & Jitapri & House & Early & Casual & Millet \\
\hline & Masanri & House & Middle & Casual & Foxtail millet? \\
\hline & Namgyeong & House & Late & Casual & Foxtail millet? \\
\hline \multirow[t]{14}{*}{ CW } & Neunggokdong & House & Middle & Flotation & $\begin{array}{l}\text { Foxtail millet }(258 / 1) \\
\quad(4770 \pm 40 \text { B.P.), } \\
\text { broomcorn millet }(3 / 2), \\
\text { azuki bean }(1 / 1), \text { wild } \\
\text { soybean? }(6 / 2)\end{array}$ \\
\hline & Seokgyori & House & Middle & Flotation & $\begin{array}{l}\text { Foxtail millet }(68 / 5) \text {, } \\
\text { broomcorn millet }(16 / 2) \text {, } \\
\text { azuki bean }(2 / 1)\end{array}$ \\
\hline & & House & Middle & Imprint & $\begin{array}{l}\text { Foxtail millet }(12 / 12) \text {, } \\
\text { broomcorn millet }(20 / 10)\end{array}$ \\
\hline & Daebudo & House & Middle & Imprint & $\begin{array}{l}\text { Foxtail millet }(2 / 2) \\
\text { broomcorn millet }(1 / 1) \text {, } \\
\text { perilla }(1 / 1)\end{array}$ \\
\hline & Jungsandong & House & Late & Flotation & $\begin{array}{l}\text { Foxtail millet }(7 / 3) \\
\quad \text { broomcorn millet }(1 / 1)\end{array}$ \\
\hline & & House & Late & Imprint & $\begin{array}{l}\text { Foxtail millet }(11 / 8) \text {, } \\
\text { broomcorn millet }(11 / 6)\end{array}$ \\
\hline & & Storage pit & Late & Imprint & Broomcorn millet $(3 / 3)$ \\
\hline & Anganggol & House & Middle & Flotation & $\begin{array}{l}\text { Foxtail millet }(19 / 2) \\
\quad \text { broomcorn millet }(1 / 1)\end{array}$ \\
\hline & Daecheonri & House & Middle & Flotation & $\begin{array}{l}\text { Foxtail millet }(4 / 1) \text {, broomcorn } \\
\text { millet }(1 / 1), \text { rice? }(6 / 1), \\
\text { barley? }(4 / 1), \text { wheat? }(3 / 1)\end{array}$ \\
\hline & Jodongri & Layers & Late & Pottery & Rice phytolith? \\
\hline & Ilsan 1 & Peat & Late & Flotation & Rice? \\
\hline & Ilsan 2 & Peat & Late & Flotation & Rice? \\
\hline & Ilsan 3 & Peat & Late & Pottery & Rice phytolith? \\
\hline & Gahyeonri & Peat & Late & Flotation & Rice?, foxtail millet? \\
\hline \multirow[t]{3}{*}{$\mathrm{CE}$} & Munamri & House & Middle & Flotation & $\begin{array}{l}\text { Foxtail millet }(2 / 1) \text {, millet } \\
\qquad(1 / 1) \text {, soybean }(4 / 2), \text { wheat? } \\
(1 / 1)\end{array}$ \\
\hline & & Outdoor features & Middle & Flotation & $\begin{array}{l}\text { Foxtail millet }(1 / 1) \\
\text { broomcorn millet }(1 / 1) \\
\text { soybean }(4 / 2), \text { rice? }(1 / 1)\end{array}$ \\
\hline & & House, etc. & Middle & Imprint & Foxtail millet (5), perilla (1) \\
\hline \multirow[t]{5}{*}{ SE } & Dongsamdong & Shell midden & Initial & Imprint & Broomcorn millet (1) \\
\hline & & Shell midden & Early & Imprint & $\begin{array}{l}\text { Foxtail millet (18) (from } \\
\text { several potsherds) }\end{array}$ \\
\hline & & House & Middle & Flotation & $\begin{array}{r}\text { Foxtail millet }(75)(4590 \pm 100 \\
\text { B.P.), broomcorn millet }(16)\end{array}$ \\
\hline & & House & Middle & Imprint & $\begin{array}{l}\text { Foxtail millet }(3 / 1) \\
\text { broomcorn millet }(2 / 2) \\
\text { perilla }(2 / 1)\end{array}$ \\
\hline & & Shell midden & Final & Imprint & $\begin{array}{l}\text { Foxtail millet (3), broomcorn } \\
\text { millet (4) }\end{array}$ \\
\hline
\end{tabular}

(Continued) 
TABLE 2 (Continued)

\begin{tabular}{|c|c|c|c|c|c|}
\hline REGION & SITE & FEATURE & PHASE & METHOD & $\begin{array}{c}\text { CROPS AND LEGUMES } \\
\text { (NUMBER OF GRAINS/FEATURES) }\end{array}$ \\
\hline \multirow{3}{*}{\multicolumn{2}{|c|}{ Bibongri }} & Shell midden & Early & Flotation & Foxtail millet (1) \\
\hline & & Outdoor features & Early & Flotation & Foxtail millet $(1 / 1)$ \\
\hline & & Outdoor features & Early & Imprint & $\begin{array}{l}\text { Foxtail millet }(4 / 1) \text {, } \\
\text { broomcorn millet }(3 / 1) \text {, } \\
\text { azuki bean }(1 / 1)\end{array}$ \\
\hline & Sangchonri 3 & Outdoor features & Late & Flotation & $\begin{array}{l}\text { Foxtail millet }(110 / 8) \text {, } \\
\text { broomcorn millet }(26 / 8)\end{array}$ \\
\hline & Sangchonri B & Outdoor features & Late & Flotation & $\begin{array}{l}\text { Foxtail millet ( } 4060 \pm 140 \\
\text { B.P.), broomcorn millet }\end{array}$ \\
\hline & Eoeun 1 & Outdoor features & Late & Flotation & $\begin{array}{l}\text { Foxtail millet }(31 / 4) \\
\quad(4030 \pm 100 \text { B.P), } \\
\text { broomcorn millet }(13 / 2), \\
\text { wild legume }(5 / 2)\end{array}$ \\
\hline \multirow{2}{*}{\multicolumn{2}{|c|}{ Pyeonggeo 3-1 }} & Outdoor features & Late & Flotation & $\begin{array}{l}\text { Foxtail millet }(1475 / 5), \\
\text { broomcorn millet }(1438 / 4), \\
\text { azuki bean }(42 / 6) \\
(4175 \pm 25 \text { B.P), soybean } \\
(59 / 5)(4200 \pm 40 \text { B.P), rice? } \\
(1 / 1), \text { wheat? }(7 / 2)\end{array}$ \\
\hline & & House & Late & Flotation & $\begin{array}{l}\text { Foxtail millet (146/1) } \\
\quad(3940 \pm 20 \text { B.P), broomcorn } \\
\quad \text { millet }(2747 / 1)\end{array}$ \\
\hline \multirow{3}{*}{\multicolumn{2}{|c|}{ Pyeonggeo 4-1 }} & House & Middle & Flotation & $\begin{array}{l}\text { Foxtail millet }(71 / 2) \\
\text { broomcorn millet }(33 / 2) \text {, } \\
\text { soybean }(3 / 1) \text {, azuki bean } \\
(10 / 1)\end{array}$ \\
\hline & & House & Late & Flotation & $\begin{array}{l}\text { Foxtail millet }(14 / 2) \text {, perilla } \\
\qquad(1 / 1)\end{array}$ \\
\hline & & Outdoor features & Late & Flotation & $\begin{array}{l}\text { Foxtail millet }(1485 / 7), \\
\text { broomcorn millet }(229 / 2), \\
\text { soybean }(4 / 2) \text {, azuki bean } \\
(8 / 4), \text { perilla }(8 / 3), \text { wheat? } \\
(23 / 4)\end{array}$ \\
\hline \multirow{2}{*}{\multicolumn{2}{|c|}{ Songjukri }} & House & Middle & Imprint & $\begin{array}{l}\text { Foxtail millet }(5 / 2) \text {, } \\
\text { broomcorn millet }(7 / 2) \text {, } \\
\text { perilla }(1 / 1)\end{array}$ \\
\hline & & Outdoor features & Middle & Imprint & $\begin{array}{l}\text { Foxtail millet }(1 / 1) \text {, } \\
\text { broomcorn millet }(1 / 1), \\
\text { perilla }(1 / 1)\end{array}$ \\
\hline & Jijwari & House & Late & Imprint & $\begin{array}{l}\text { Foxtail millet }(1 / 1) \\
\quad \text { broomcorn millet }(1 / 1)\end{array}$ \\
\hline & Bonggyeri & Finds & Late & Imprint & $\begin{array}{l}\text { Broomcorn millet (3), perilla } \\
\text { (1) }\end{array}$ \\
\hline
\end{tabular}

Notes: $\quad \mathrm{NW}=$ northwestern,$\quad \mathrm{CW}=$ central-western,$\quad \mathrm{CE}=$ central-eastern,$\quad \mathrm{SE}=$ southeastern; Imprint $=$ crop impressions on pottery sherds; crop? = dubious identification or date.

* Soybean, azuki bean, and perilla include both wild and domesticated species because of identification difficulties.

Data sources: Ahn 2013; Lee 2011; Nakayama 2014 
Despite the intensive use of acorns in this period, Korean archaeologists assumed that subsistence in the Initial and Early Neolithic in southern Korea depended heavily on exploitation of sea resources and not at all on plant cultivation (Ahn 2005, 2006, 2014). Recent SEM investigation of plant impressions on potsherds, however, revealed grain impressions of foxtail and broomcorn millets on Early Neolithic pottery from the Bibong-ri and Dongsam-dong sites as well as one broomcorn millet impression on Initial Neolithic pottery from the Dongsam-dong site (Obata 2013). These findings have raised a controversy over whether millet cultivation existed as early as the fifth millennium B.C., about a thousand years earlier than previously thought.

Considering the exchange sphere that connected southern Korea with northeastern China, we do not deny the possibility of the existence of millet resources in the Initial phase. Nevertheless, we are skeptical about millet cultivation during the Initial phase because definite evidence for millet being locally cultivated, rather than traded for, and reliable criteria for distinguishing wild from domesticated broomcorn millet grains are still insufficient (Ahn 2012a). In addition, site locations, stone and bone tool composition, animal remains, and stable isotopic analyses of human bones taken together commonly indicate marine-oriented subsistence during the Initial phase (Choy et al. 2012), but provide no clear evidence of sedentism (Ahn 2014).

If millet had been cultivated during the Early phase in southern Korea, the prevailing opinion that millet cultivation was adopted into this area from the central-western Korean Chulmun Culture during the Middle Neolithic would have to be revised. However, not only Initial phase sites but also Early phase sites are mainly located on islands and coastal areas, strongly suggesting a subsistence economy that heavily relied on sea resources. In addition, the appearance of Chulmun pottery along with new stone tool assemblages including polished stone arrowheads, spades, and saddle querns in the Middle phase indicate that millet cultivation would have been introduced from central-western Korea.

\section{Rice Cultivation}

Whether or not rice was cultivated in Neolithic Korea has long been debated. Based on archaeological evidence such as waterlogged rice husks from peats in the Lower Han River valley, rice phytoliths recovered from pottery, and carbonized grains of rice, barley, and wheat recovered from the Daecheon-ri site in Okcheon, Shin, Rhee, and Aikens (2012:89) argue that rice was cultivated during the Neolithic. Rice as well as wheat may have diffused into the Korean Peninsula from Shandong, China, where rice and wheat had been cultivated together with millet since the Lungshan period (Miyamoto 2009; Zhao 2011). We remain skeptical of this conclusion, and believe the data they used as evidence may have been misidentified or contaminated (Ahn 2010:90-91). We here add two more reasons for our reluctance to accept Neolithic rice cultivation (Ahn 2013).

Foxtail and broomcorn millet remains have been recovered from flotation samples from Middle and Late phase sites, but only two grains of rice larger in size than millet have been reported (Lee 2011; NRICH 2013). Lee (2011) examined these rice grains and suggested that they may have intruded later into the sample. SEM examination of plant impressions on pottery also counters the Neolithic rice cultivation hypothesis (Nakayama 2014; Obata 2013). Most grain impressions have been identified as foxtail 
Table 3. Numbers of Sites and Features with Crop Remains from Flotation* AND IMPRESSIONS ON POTTERY

\begin{tabular}{|c|c|c|c|c|c|c|c|c|}
\hline & & FOXTAIL & BROOMCORN & AZUKI & & BEEFSTEAK & & \\
\hline CROPS & & MILLET & MILLET & BEAN & SOYBEAN & PLANT & RICE & WHEAT \\
\hline \multirow[t]{2}{*}{ Impression } & Sites & 6 & 5 & 1 & 0 & 6 & 0 & 0 \\
\hline & Features & 19 & 19 & 1 & 0 & 8 & 0 & 0 \\
\hline \multirow[t]{2}{*}{ Flotation } & Sites & 12 & 12 & 3 & 5 & 2 & 2 & 3 \\
\hline & Features & 48 & 35 & 12 & 12 & 6 & 2 & 9 \\
\hline
\end{tabular}

Data sources: Ahn 2013; Nakayama 2014; Obata 2013.

* Flotation results from Lee $(2003,2011)$, who assumed rice and wheat were later intrusions.

and broomcorn millets. Not a single rice grain impression on Neolithic pottery has been discerned, although rice is much larger than any millet (Table 3). This contrasts with the frequent reports of rice grain impressions on Bronze Age pottery. Even if rice was sometimes cultivated during the Neolithic, it was not widespread; perhaps rice was cultivated in a very limited area or only for a special purpose such as use during rituals.

\section{VARIATIONS IN HOUSES AND SETTLEMENTS BY TEMPORAL PHASE \\ Central-Western Korea}

Considering geographical differences in temporal sequences, we divide the centralwestern Korean region in which Chulmun pottery first appeared into three sub-areas: coastal-island Gyeonggi areas, the Han River valley, and the Chungcheong area, including the lower and middle Geum River valley (Table 4). We adopt Lim's (2012) relative chronology with some revisions by radiocarbon dates.

Islands and Coastal Areas of Gyeonggi - Previously, Korean archaeologists believed that Neolithic settlements in central-western Korea were situated only on inland riverbanks, while short-term camps were set up on the islands and coasts for gathering shellfish and fishing. However, recent excavations on large and small islands, especially Youngjong-do Island, the largest offshore island in the area, reveal many settlements varying in size. Dating to the early forth millennium B.C., Unseo-dong site represents the oldest Early phase settlement on Youngjong-do Island (CICH 2010). Clusters of 58 houses in Location 2 and 8 houses in Location 1 formed villages on a lower hill near the coast (Fig. 1).

During the Middle phase, settlements spread to nearby islands, including the Sammok-do and Daebu-do islands; some houses at the Unseo-dong site also remained occupied until this phase. Settlements appeared in coastal hilly zones of mainland Korea during the Middle phase. Plant food-processing tools such as saddle querns and grinding stones have been found at most settlements. So (2013a:59) suggests that the span of occupation at Unseo-dong and other sites during the Middle phase was less than during the Early Neolithic. Food resources were likely accessed via logistical movement to resource patches (Kim 2010).

Settlements disappeared from the mainland coast during the Late phase, but remained at a significant scale on Youngjong-do Island, as seen at the Jungsan-dong and Unbuk-dong sites (CICH 2011; HICH 2012a, 2012b). Among the 10 houses at 
Table 4. Neolithic Central Korean Sites (Number of Houses in Parentheses)

\begin{tabular}{|c|c|c|c|c|c|c|}
\hline PHASE B.C. & $\begin{array}{c}\text { GYEONGGI } \\
\text { ISLANDS }\end{array}$ & $\begin{array}{c}\text { GYEONGGI } \\
\text { COAST }\end{array}$ & $\begin{array}{l}\text { CHUNG- } \\
\text { CHEONG }\end{array}$ & $\begin{array}{c}\text { LOWER AND } \\
\text { MIDDLE HAN } \\
\text { RIVER }\end{array}$ & $\begin{array}{l}\text { UPPER HAN } \\
\text { RIVER }\end{array}$ & $\begin{array}{c}\text { GWANGWON } \\
\text { COAST }\end{array}$ \\
\hline $\begin{array}{l}\text { Early } \\
\qquad 4000-3500\end{array}$ & $\begin{array}{l}\text { Unseo I (8), } \\
\text { II (58), III (1) } \\
\text { Ggachisan (1) }\end{array}$ & & & $\begin{array}{l}\text { Samgeo (6) } \\
\text { Amsa (30) }\end{array}$ & Jucheon (3) & \\
\hline $\begin{array}{l}\text { Middle } \\
\quad 3500-2900\end{array}$ & $\begin{array}{l}\text { Sammok (17) } \\
\text { Daebu (19) } \\
\text { Nundeul (1) } \\
\text { Jeokgae (3) } \\
\text { Gaeundaesalmak } \\
\quad \text { (3) }\end{array}$ & $\begin{array}{l}\text { Neunggok } \\
\quad(26) \\
\text { Singil (23) } \\
\text { Seokgyo } \\
\quad(26) \\
\text { Gyeongseo } \\
\quad(2)\end{array}$ & $\begin{array}{l}\text { (Total Sites: } \\
\text { 29) } \\
\text { Houses (59) }\end{array}$ & $\begin{array}{l}\text { Gurae (2) } \\
\text { Nongseo (8) }\end{array}$ & $\begin{array}{l}\text { Sinmae (1) } \\
\text { Seongsan (1) }\end{array}$ & $\begin{array}{l}\text { Jigyoung (10) } \\
\text { Chodang (6) } \\
\text { Gapyeong (2) } \\
\text { Songjeon (2) } \\
\text { Hasi (1) } \\
\text { Osan (2) } \\
\text { Munam (7) }\end{array}$ \\
\hline $\begin{array}{l}\text { Late } \\
\qquad 2900-2300\end{array}$ & $\begin{array}{l}\text { Jungsan (34) } \\
\text { Unbuk (17) } \\
\text { Eulwang (6) }\end{array}$ & & & $\begin{array}{l}\text { Dangdong (7) } \\
\text { Deoksong (3) } \\
\text { Gajae(1) } \\
\text { Jisaeul (3) } \\
\text { Sasong (1) } \\
\text { Gurae (4) } \\
\text { Hwajeob (1) } \\
\text { Sanghyeon } \\
\quad(1)\end{array}$ & $\begin{array}{l}\text { Auraji (3) } \\
\text { Geodu (1) } \\
\text { Yeoknae (3) } \\
\text { Bangok (2) }\end{array}$ & $\begin{array}{l}\text { Cheoltong (7) } \\
\text { Chodang (1) }\end{array}$ \\
\hline $\begin{array}{l}\text { Final } \\
\qquad 2300-1500\end{array}$ & $\begin{array}{l}\text { Jungsan (3) } \\
\text { Unbok (1) } \\
\text { Moido (2) }\end{array}$ & & & & $\begin{array}{l}\text { Bangok (1) } \\
\text { Cheonjon } \\
\quad(1) \\
\text { Sinweol (1) }\end{array}$ & \\
\hline
\end{tabular}

Data sources: Koo 2011; Lim 2012.

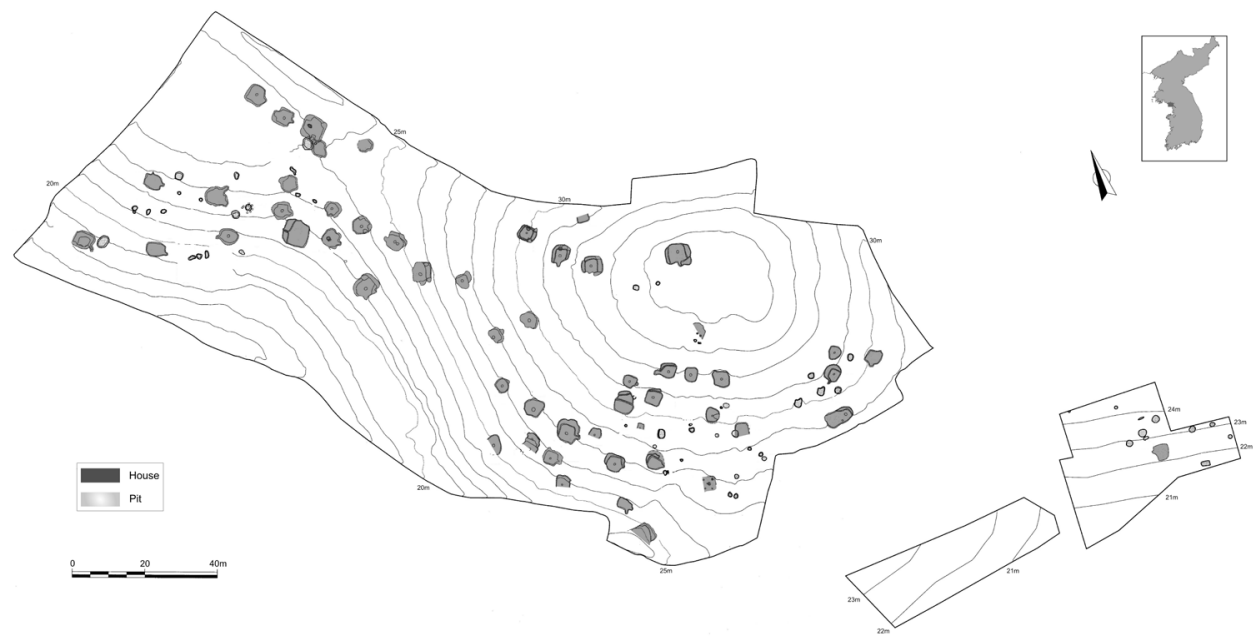

Fig. 1. House distribution in Unseo-dong (Location 2) Early phase settlement. 
Location 21 and 21 houses at Location 23 at the Jungsan-dong site, only 3 are dated to the Final phase. This is in contrast to earlier large settlements with clustered houses, such as the Unseo-dong settlement, where between 1 and 4 houses were scattered on a hill ridge at the Jungsan-dong site (Fig. 2). At the Unbuk-dong site, 15 dwellings and numerous outdoor hearths were found in 7 localities. Houses of the Late phase show multiple, disorganized postholes and overlapping hearths, indicating repeated occupation.

Opinions differ concerning the degree of sedentism in the Late phase. Based on house structure and the diversity of tool composition and outdoor features, Yoo (2012) suggests that the span of occupation and degree of sedentism increased during the Late phase, while settlements during the Middle phase were occupied for a relatively short period of time. By contrast, So $(2013 a, 2013 b)$ argues that Late phase settlement patterns show short-term (seasonal or every few years) residential movements. According to him, the small size of house clusters and the reuse of living floors during the Late phase relate to a reduction in settlement size and weakening sedentism. Of these two scenarios, So's accords better with our analysis of radiocarbon dates shown below.

Settlement size was greatly reduced during the Final phase. Large-scale settlements were abandoned, but later a number of outdoor hearths and pits were constructed in them. Sedentary houses disappeared while limited-activity stations such as outdoor hearths and shell middens increased in number. Camps for acquiring and processing marine resources remained in coastal areas during the Final phase.

The Han River Valley - Settlements with pit houses appeared on riverbanks during the Early phase around the early fourth millennium B.C. At least 30 houses have been revealed in the Amsa-dong settlement, along with open-air hearths and pottery kilns (Shin et al. 2012:77). The diversity of stone tools, including arrowheads, net sinkers, axes, digging tools, and grinding slabs, suggests diverse subsistence strategies. Research to capture plant remains by flotation has not yet been conducted, however.

The total number of houses in the Han River valley decreased in the Middle phase compared to the Early phase. Settlement size also reduced in the late fourth millennium B.C. Except at the Nongseo-ri site, where 8 dwellings and 38 small pits were found, Middle phase settlements consisted of only one or two houses (GCHRC 2009). The number of settlements increased in the upper Han River valley during the Late phase, but settlements usually consisted of a single house. Although some sites revealed 3-7 houses, each house overlapped others or was isolated from others by long distances.

The size of individual house floors did not change significantly over time. The average size of Early phase dwellings $(\mathrm{N}=26)$ is $26.4 \pm 9.3 \mathrm{~m}^{2}$, Middle phase $(\mathrm{N}=8)$ is $21.8 \pm 17.8 \mathrm{~m}^{2}$, and Late phase $(\mathrm{N}=8)$ is $24.9 \pm 13.8 \mathrm{~m}^{2}$. During the Final phase, houses became very rare, while outdoor features such as open-air hearths still existed in many places. Settlements have not been found from inland Gyounggi Province, but a few houses have been reported from the upper Han River basin.

Chungcheong - There was a settlement explosion around the late fourth millennium B.C. in coastal and inland areas of the Chungcheong area. A total of 59 houses have been found in 29 Middle phase sites. No large settlements have been found; most settlements consist of a single house located on a hilltop. Some settlements may have been the result of people spreading out from the island and coastal zones of the 


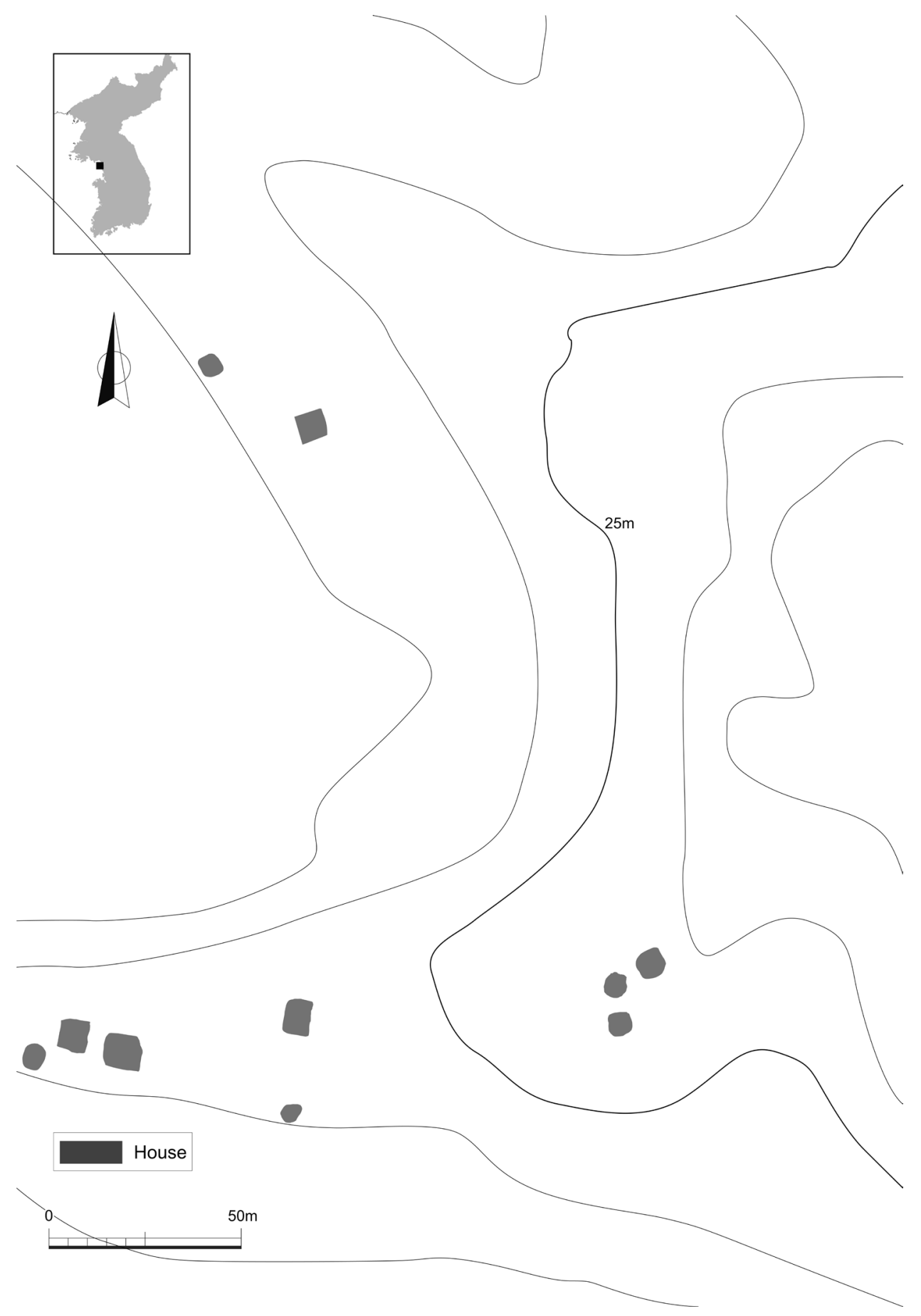

Fig. 2. House distribution in Jungsan-dong (Location 21) Late phase settlement. 
Gyounggi Province, since both provinces show similar house structures (Koo $2011,2013)$. Average house size is $21.5 \pm 12.0 \mathrm{~m}^{2}(\mathrm{~N}=25)$ in coastal areas and $36.3 \pm 20.9 \mathrm{~m}^{2}(\mathrm{~N}=10)$ in inland areas. Settlements disappeared from the area in the Late phase, but specialized task-oriented field camps and shell middens continued.

Summary - Large-scale settlements appeared first on Youngjong-do Island and in the Han River valley during the Early phase. In the Middle phase the number of settlements increased dramatically (more than twenty-fold) and the number of houses doubled. Large settlements were actively occupied in island-coastal areas. In inland areas, however, settlements reduced in size and spread to hilly zones or the upper Han River valley. Isolated small settlements or individual houses appeared in the Chungcheong provinces, including the Geum River valley, during the Middle Neolithic. During the Late phase both settlements and houses sharply decreased in number. During the Final phase, settlements and dwellings became even fewer, with the number of settlements reduced to one-third and dwellings to one-tenth their former numbers, probably indicating weakening sedentism or rapid population decline (Table 4).

\section{Central-Eastern Coast}

On the central-eastern coast, residential fishing camps were occupied in the Initial phase (6000-4500 B.C.). Early phase sites (4500-3500 B.C.) have not been discovered in this area. During the late fourth millennium B.C. of the Middle phase, settlements appeared on coastal sand dunes, probably established by migrants from the advanced central-western Chulmun Culture. Southern-style Chulmun pottery also appeared in this area during the Middle phase. Middle-sized settlements of 5-10 houses coexisted with small-sized settlements of 1 or 2 houses. The numbers of dwellings and settlements markedly decreased in the Late phase. The sizes of Late phase dwellings $(\mathrm{N}=5$ : $\left.20.6 \pm 6.8 \mathrm{~m}^{2}\right)$ are also smaller than Middle phase dwellings $\left(\mathrm{N}=15: 36.8 \pm 9.6 \mathrm{~m}^{2}\right)$. No evidence suggests demographic growth during the Late phase.

The Cheoltong-ri site, with seven houses, dates to the early third millennium B.C. (4300-4200 uncal B.P.) (YICP 2008), which puts it as early as the Late phase (3000-2500 B.C.) in our chronological scheme. Referring to the Cheoltong-ri site, Shin, Rhee, and Aikens (2012:88) argue that villages in this area thrived during the "Late Neolithic." However, they define the Late Neolithic as lasting from 2500 to 1500 B.C., which we refer to as the Final phase (2300-1500 B.C.). Houses and settlements dating to the Final phase are as absent in this area as in central-western Korea.

\section{Southern Korea}

Initial phase sites are distributed along the southern coast, most of which are shell middens with little evidence for substantial sedentism. No dwellings have yet been found yet for this phase. Burials, however, were found from several sites. Small storage pits for acorns also appeared from this phase. Obsidian goods suggest long-distance trade with Kyushu, Japan (Shin et al. 2012). The distribution and frequency of Early phase sites are similar to those from the Initial phase. Sites are still mostly shell middens from seasonal and base camps (Lee 2001, 2006). Pit houses appeared, but are rare; their inner structures do not show substantial occupation, although the existence of burials, 
Table 5. Southern Korean Neolithic Settlements (Number of Houses Indicated in Parentheses)

\begin{tabular}{ll}
\hline PHASE & \multicolumn{1}{c}{ SITES WITH HOUSES } \\
\hline Initial & None \\
Early & Bibong (3), Dongsam (1), Mokdo (2) \\
Middle & Dongsam (2), Sangchon (15), Pyeonggeo (4), Songjuk (9), Jijwa (2), Galmeori (3), \\
& Jingeuneul (1), Bonggil (3) \\
Late & Sangchon (15), Pyeonggeo (6), Jijwa (5), Bonggye (11), Imbul (4), Yucheon (1), \\
& Seobyeon (1), Daebong (2) \\
Final & Geumcheon (2), Daecheon (1) \\
\hline
\end{tabular}

Data sources: Ha 2006; Koo 2011.

storage pits, thick layers of shell midden, and a large amount of pottery suggest a gradual increase in the degree of sedentism compared to the Initial phase.

A rather marked change took place in southern Korea in the late fourth millennium B.C. when the Chulmun material culture appeared along with comb-pattern pottery and new polished stone tools such as arrowheads, net sinkers, and saddle querns. During this Middle phase, the exploitation not only of sea resources but also of terrestrial resources intensified and millet cultivation was adopted. Sedentary settlements appeared and rapidly spread along inland riverbank areas. Large or middle-sized settlements with clustered houses were distributed on the sandy alluvial plain in middle and lower reaches of rivers. Settlements were distributed more sparsely in the upper reaches and consisted of only one to three houses (Ahn 2006). Unlike in centralwestern Korea, houses have not been reported on the southern coast and islands, except for two houses at Dongsam-dong (Busan Museum 2007).

The number of houses and settlements and subsistence patterns in the Late phase are similar to those of the Middle phase (Table 5). However, a comparison of house size within Sangchon-ri and Pyeonggeo settlements, both of which were occupied continuously during the Middle to Late phases, indicates that the average size of houses became smaller in the Late phase (Middle phase: $36.8 \pm 9.6 \mathrm{~m}^{2}$ at Sangchonri, $45.2 \pm 18.0 \mathrm{~m}^{2}$ at Pyeonggeo; Late phase: $27.2 \pm 15.1 \mathrm{~m}^{2}$ at Sangchon-ri, $35.2 \pm 17.1$ $\mathrm{m}^{2}$ at Pyeonggeo). Inter-house difference in size became larger in the Late phase at both sites, but it is not certain whether this related to increased social complexity. Regardless of the change in size, houses in this area were generally large.

Settlement almost disappeared during the Final phase (dated to the late third and second millennium B.c.) in this area as was the case in the other areas already discussed. Only two sites consisting of one or two houses each have been reported (Koo 2011). On the other hand, the number of shell middens increased again along the southern coast and on the islands. In areas inland, most Final phase sites are open hearths, rock shelters, and scattered finds, showing little evidence of sedentism.

To summarize, large-scale settlements first appeared in the Early phase of centralwestern Korea. In the Middle phase, the number of houses and settlements markedly increased, and central-western Korean material culture simultaneously spread to the central-eastern coast and southern Korea. This Middle Neolithic expansion coincided with a period of population increase. During the Late phase, the number of houses and settlements greatly decreased; Final phase houses are extremely rare (Table 6). 
Table 6. Number of Settlements/Houses by Region and Phase

\begin{tabular}{|c|c|c|c|c|c|c|c|c|c|}
\hline PHASE & $\begin{array}{c}\text { CW } \\
\text { ISLAND }\end{array}$ & $\begin{array}{c}\text { CW } \\
\text { COAST }\end{array}$ & CWS & $\begin{array}{c}\text { CW } \\
\text { INLAND }\end{array}$ & $\begin{array}{c}\text { CE } \\
\text { INLAND }\end{array}$ & $\begin{array}{c}\text { CE } \\
\text { COAST }\end{array}$ & $\begin{array}{c}\text { CENTRAL } \\
\text { TOTAL }\end{array}$ & SOUTHERN & TOTAL \\
\hline Early & $68 / 2$ & & & $36 / 2$ & $3 / 1$ & & $107 / 4$ & $6 / 3$ & $113 / 7$ \\
\hline Middle & $42 / 5$ & $77 / 4$ & $59 / 29$ & $10 / 2$ & $2 / 2$ & $30 / 7$ & $220 / 69$ & $39 / 8$ & $259 / 77$ \\
\hline Late & $57 / 3$ & & & $21 / 8$ & $8 / 4$ & $8 / 2$ & $94 / 17$ & $45 / 8$ & $139 / 25$ \\
\hline Final & $6 / 3$ & & & & $3 / 3$ & & $9 / 6$ & $3 / 2$ & $12 / 8$ \\
\hline
\end{tabular}

Note: $\mathrm{CW}=$ central-western; CWS = central-western south $($ Chungcheong Province) $\mathrm{CE}=$ centraleastern.

\section{RADIOCARBON DATES AND TEMPORAL VARIATION OF HOUSE NUMBERS}

So far, the discussion of temporal changes in number and distribution of houses and settlements has been based on relative chronology and phase division. We now move on to radiocarbon dates, analyzing about 280 radiocarbon dates from 148 dwellings and 330 dates from outdoor features, including shell middens. We use uncalibrated B.P. dates to monitor temporal change in numbers of settlements and houses (Tables 7 and 8). This is followed by a comparison with summed probability distributions of calibrated dates.

When using uncalibrated B.P. dates for analysis, if multiple radiocarbon dates were reported from a single feature, we chose only one date by applying the following two criteria. First, dates measured from short-lived plants such as seeds were chosen over

Table 7. Uncalibrated Radiocarbon Dates from Houses

\begin{tabular}{lcccccccc}
\hline & CW & CW & CWS & CWS & CE & & & \\
UNCAL B.P. & COAST & INLAND & COAST & INLAND & COAST & S COAST & S INLAND & TOTAL \\
\hline $6000-5000$ & 1 & 1 & 0 & 0 & 9 & 1 & 0 & 12 \\
$4900 \mathrm{~s}$ & 6 & 2 & 0 & 0 & 0 & 0 & 0 & 8 \\
$4800 \mathrm{~s}$ & 4 & 3 & 0 & 0 & 0 & 0 & 0 & 7 \\
$4700 \mathrm{~s}$ & 12 & 4 & 0 & 0 & 1 & 0 & 0 & 17 \\
$4600 \mathrm{~s}$ & 12 & 4 & 3 & 0 & 5 & 0 & 1 & 25 \\
$4500 \mathrm{~s}$ & 11 & 1 & 4 & 0 & 3 & 1 & 2 & 22 \\
$4400 \mathrm{~s}$ & 6 & 0 & 1 & 6 & 3 & 0 & 1 & 17 \\
$4300 \mathrm{~s}$ & 6 & 6 & 2 & 2 & 2 & 1 & 1 & 19 \\
$4200 \mathrm{~s}$ & 7 & 1 & 0 & 2 & 4 & 0 & 1 & 16 \\
$4100 \mathrm{~s}$ & 6 & 3 & 0 & 0 & 1 & 0 & 0 & 10 \\
$4000 \mathrm{~s}$ & 3 & 5 & 0 & 0 & 0 & 0 & 2 & 10 \\
$3900 \mathrm{~s}$ & 1 & 1 & 0 & 0 & 0 & 0 & 2 & 4 \\
$3800 \mathrm{~s}$ & 0 & 1 & 0 & 0 & 0 & 0 & 0 & 1 \\
$3700 \mathrm{~s}$ & 2 & 0 & 0 & 0 & 0 & 0 & 0 & 2 \\
$3600 \mathrm{~s}$ & 2 & 3 & 0 & 0 & 0 & 0 & 0 & 5 \\
$3500 \mathrm{~s}$ & 0 & 0 & 0 & 0 & 0 & 0 & 0 & 0 \\
$3400 \mathrm{~s}$ & 1 & 0 & 0 & 0 & 0 & 0 & 0 & 1 \\
$3300 \mathrm{~s}$ & 1 & 1 & 0 & 0 & 0 & 0 & 0 & 2 \\
$3200-3000$ & 0 & 0 & 0 & 0 & 0 & 0 & 0 & 0 \\
\hline
\end{tabular}

$\mathrm{CW}=$ central-western; CWS $=$ Chungcheong Province; $\mathrm{CE}=$ central-eastern; $\mathrm{S}=$ southern.

The latest date is chosen if multiple dates were obtained from an individual house. Separate dates are given if houses were occupied repeatedly. 
Table 8. Uncalibrated Radiocarbon Dates of Outdoor Features (One Date Per Individual Feature)

\begin{tabular}{|c|c|c|c|c|c|c|c|c|c|c|c|c|}
\hline & CW & CW & CWS & CWS & $\mathrm{CE}$ & S & S & & CW & CWS & S & SHELL \\
\hline UNCAL B.P. & COAST & INLAND & COAST & INLAND & COAST & COAST & INLAND & TOTAL & SHELL & SHELL & SHELL & TOTAL \\
\hline $6000-5000$ & 6 & 3 & 7 & 0 & 1 & 5 & 0 & 22 & 13 & 4 & 16 & 33 \\
\hline $4900 \mathrm{~s}$ & 0 & 1 & 1 & 0 & 0 & 2 & 0 & 4 & 0 & 0 & 3 & 3 \\
\hline $4800 \mathrm{~s}$ & 0 & 0 & 0 & 0 & 0 & 0 & 0 & 0 & 0 & 1 & 0 & 1 \\
\hline $4700 \mathrm{~s}$ & 6 & 0 & 0 & 0 & 0 & 0 & 0 & 6 & 0 & 0 & 0 & 0 \\
\hline $4600 \mathrm{~s}$ & 4 & 0 & 0 & 0 & 0 & 2 & 0 & 6 & 0 & 1 & 2 & 3 \\
\hline $4500 \mathrm{~s}$ & 0 & 0 & 2 & 0 & 0 & 0 & 3 & 5 & 0 & 2 & 3 & 5 \\
\hline $4400 \mathrm{~s}$ & 6 & 2 & 2 & 0 & 0 & 0 & 7 & 17 & 0 & 0 & 3 & 3 \\
\hline $4300 \mathrm{~s}$ & 2 & 4 & 0 & 0 & 0 & 1 & 7 & 14 & 0 & 1 & 3 & 4 \\
\hline $4200 \mathrm{~s}$ & 7 & 1 & 0 & 0 & 1 & 0 & 2 & 11 & 1 & 3 & 3 & 7 \\
\hline $4100 \mathrm{~s}$ & 2 & 4 & 0 & 0 & 1 & 1 & 3 & 11 & 0 & 4 & 2 & 6 \\
\hline $4000 \mathrm{~s}$ & 6 & 6 & 0 & 0 & 0 & 0 & 6 & 18 & 3 & 2 & 0 & 5 \\
\hline $3900 \mathrm{~s}$ & 2 & 7 & 2 & 0 & 2 & 0 & 0 & 13 & 1 & 1 & 2 & 4 \\
\hline $3800 \mathrm{~s}$ & 14 & 6 & 2 & 0 & 1 & 0 & 1 & 24 & 0 & 3 & 1 & 4 \\
\hline $3700 \mathrm{~s}$ & 8 & 4 & 0 & 0 & 2 & 0 & 1 & 15 & 0 & 0 & 1 & 1 \\
\hline $3600 \mathrm{~s}$ & 10 & 0 & 0 & 0 & 1 & 0 & 1 & 12 & 0 & 0 & 1 & 1 \\
\hline $3500 \mathrm{~s}$ & 11 & 2 & 0 & 0 & 1 & 0 & 5 & 19 & 0 & 0 & 1 & 1 \\
\hline $3400 \mathrm{~s}$ & 15 & 0 & 0 & 0 & 3 & 0 & 4 & 21 & 0 & 0 & 1 & 1 \\
\hline $3300 \mathrm{~s}$ & 14 & 1 & 0 & 0 & 0 & 0 & 0 & 15 & 0 & 2 & 1 & 3 \\
\hline $3200-3000$ & 4 & 0 & 0 & 0 & 2 & 0 & 0 & 6 & 0 & 3 & 2 & 5 \\
\hline
\end{tabular}

$\mathrm{CW}=$ central-western ; CWS = Chungcheong Province; $\mathrm{CE}=$ central-eastern; $\mathrm{S}=$ southern.

The latest date is chosen if multiple dates were obtained from an individual feature. Dates from marine animals including shells are calculated separately from charcoal samples because of marine reservoir effect. Dates from shell middens are chosen by separate layers or by intervals of 100 years if with long occupation.

wood charcoals. Second, the latest dates were chosen over earlier dates. Both criteria were applied to avoid the possible "old wood problem" (Schiffer 1986). We eliminated outliers and any dates that seemed extremely unreliable compared with our current chronology.

\section{Central-Western Korea}

Except for one house at Unseo-dong dated to $5040 \pm 50$ uncal B.P., houses appeared from 5000 uncal B.P. in the island-coastal areas of Gyounggi Province (CICH 2010). The number of radiocarbon dates from houses increased two to three times during $\mathrm{c}$. 4800-4500 uncal B.P., suggesting a rapid increase in the number of houses. The number of houses begins to drop around 4500 uncal B.P.; this tendency continues until 3300 uncal B.P., the beginning of the Bronze Age. In sharp contrast, radiocarbon dates from outdoor features increased greatly starting around 3800 uncal B.P. At the Jungsan-dong and Unbuk-dong sites, where both houses and outdoor features were found, outdoor features tend to have younger dates, suggesting that outdoor features were used increasingly over time (Fig. 3).

A very similar pattern is found in the Han River valley. Settlements flourished from 5000-4600 uncal B.P. and houses were also prevalent during the period between 4400 and 4000 uncal B.P., but decreased radically thereafter. In the Chungcheong area, 

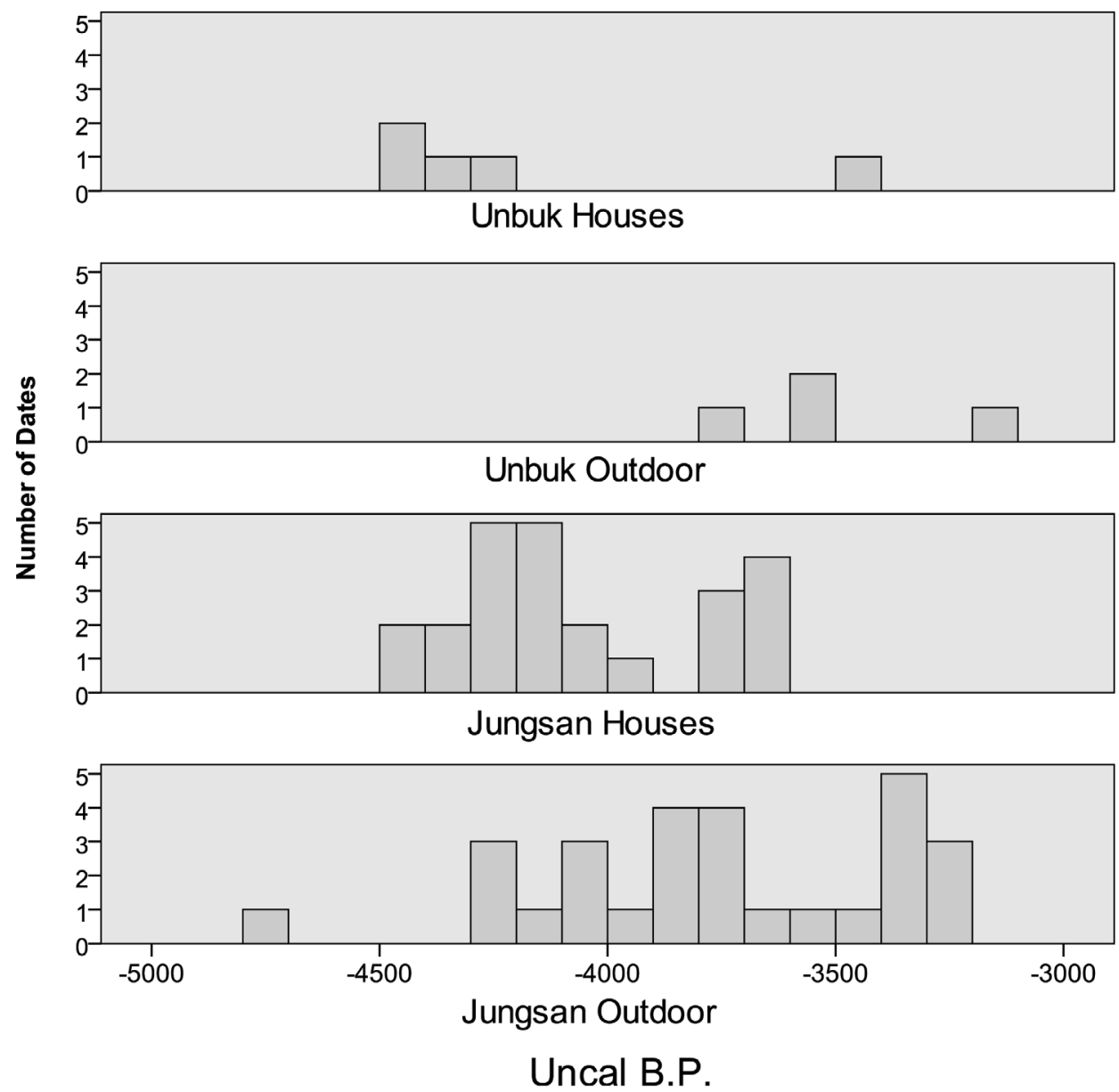

Fig. 3. Distributions of uncalibrated B.P. dates of houses and outdoor hearths from Unbuk-dong and Jungsan-dong sites.

dwellings only appear from 4700 to 4300 uncal B.P. (centered in the 4500 s) on the coast and 4500-4200 uncal B.P. (centered in the 4400s) in areas inland. Radiocarbon dates in central-western Korea therefore demonstrate a decrease in the number of houses and settlements after c. 4500-4000 uncal B.P., whereas outdoor features (including shell middens) increased from 4100 until 3300 uncal B.P., especially on the coast and islands.

\section{Central-Eastern Coast and Southern Korea}

Radiocarbon dates before 5000 uncal B.P. came from Initial phase sites with marineoriented subsistence in the central-eastern coast. Central-western-style Chulmun Culture settlements with millet cultivation appear c. 4700-4400 uncal B.P. and continue as late as 4100 uncal B.P. After 4100 uncal B.P., radiocarbon dates for houses are absent in this region. 
As already mentioned, most Initial and Early phase sites in the southern region are shell middens related to marine-oriented subsistence; radiocarbon dates for houses are scarce compared to the abundant dates for shell middens. Settlements developed during the Middle and Late phases, mainly in inland areas. Radiocarbon dates of houses are concentrated between 4700 and 3900 uncal B.P.; radiocarbon dates for outdoor features appear continuously after uncal 3900 B.P. and are especially abundant from 3600 to 3400 uncal B.P. in inland areas.

\section{Synthesis of Radiocarbon Dates}

Figure 4 demonstrates a temporal distribution of uncalibrated radiocarbon dates of houses in central-western and southern Korea. Dates of houses earlier than 5000 B.P. came from Initial phase sites on the central-eastern coast, except one date from a house at Dongsam-dong. Dates of houses during c. 5000-4800 uncal B.P. are confined to the central-western Korean islands and the Lower/Middle Han River valley. After the appearance of sedentary settlement in these areas, houses began to increase sharply c. 4800 uncal B.P. and reached their peak c. $4700-4500$ uncal B.P. After this period, the number of houses show a decreasing trend. Starting c. 4200 uncal B.P., the number of houses drops sharply. The number of houses decreased radically again in the 3900s uncal B.P.

Figure 5 shows that temporal change in the number of outdoor features (including hearths, small pits, and shell middens) is rather contrary to that of houses. While dwellings become scarce, outdoor features retain a high frequency of occurrence during 4000-3300 uncal B.P.

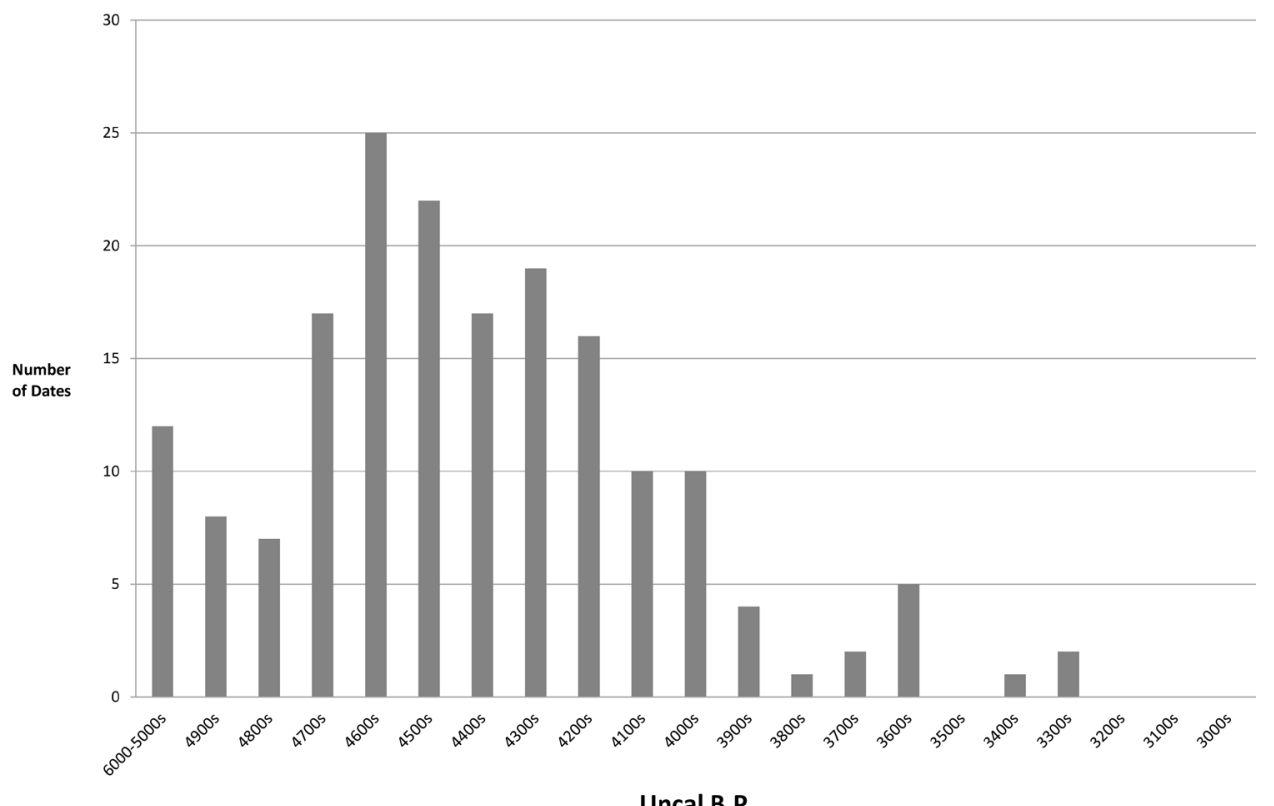

Fig. 4. Distribution of approximate uncal dates (by century B.P.) from houses in South Korea. Latest date (unless dubious) is used if multiple dates were obtained from an individual house. Separate dates are given if dwellings were occupied repeatedly. 


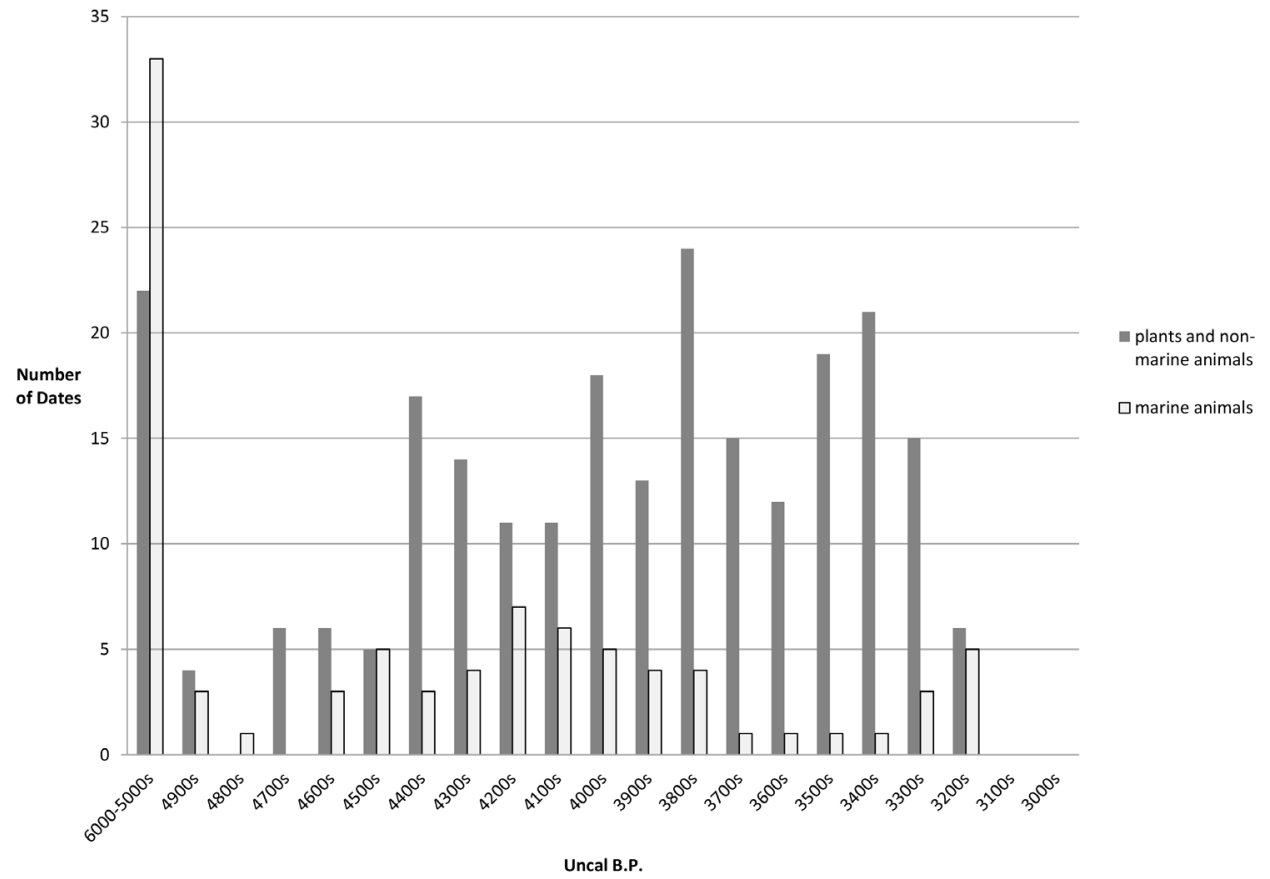

Fig. 5. Distribution of uncal B.P. dates for outdoor features (including shell middens) in South Korea. Data from marine animals are represented separately to account for marine reservoir effect.

Settlement distributions for the periods 4700-4000 and 4000-3300 uncal B.P. are compared in Figure 6 and Figure 7, respectively. These charts clearly show widespread distribution of settlements during 4700-4000 uncal B.P., followed by a marked decrease in settlements from 4000 to 3300 uncal B.P.

\section{Summed Probability Distribution of Calibrated Dates}

Figure 8 and Figure 9 illustrate summed probability distributions (SPD) using calibrated radiocarbon dates from houses and outdoor features. Both the latest date and combined dates by R_Combine order (using OxCal V4.2 software) are used if multiple dates were reported for an individual house or feature. We calibrate shell samples by applying $172 \pm 46$ years of reservoir age obtained from the southwestern coast (So 2013a:46-47). Both methods show an almost identical pattern of temporal distribution. The probability density for houses increases sharply after c. 3800 B.C. and peaks c. 3500 B.C. After 3500 B.C., it decreases until 3400 B.C. and remains stable until 3000 B.C. It then reaches another peak c. 2900 B.C. (The latter peak was not identified in the temporal variations using uncalibrated radiocarbon dates.) The latter peak is also shown in the density of outdoor features. We interpret this peak as the result of an extremely steep calibration curve between 2950 and 2850 B.C., which causes a peak in probability density (Buchanan et al. 2011). The fact that the peak is located at the exact same time as the steep period of the calibration curve suggests that it has little to do with a sudden population increase. The probability density of houses falls radically after 2850 B.C. and becomes stable again until 2500 B.C., when the Final 


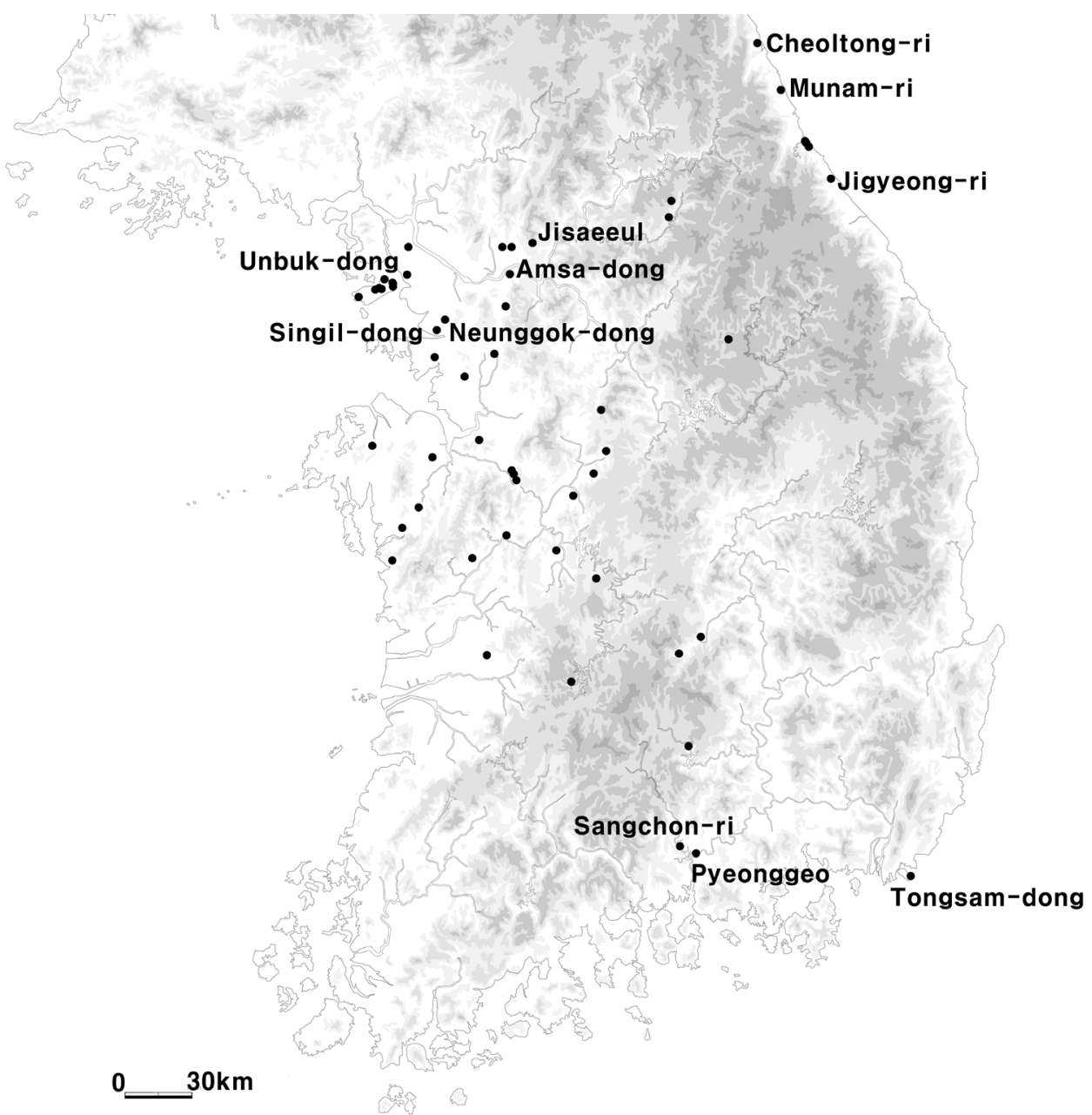

Fig. 6. Distribution of settlements dated 4700-4000 uncal B.P.

phase begins. The probability density drops sharply again at 2500 B.C. The Final phase (2500-1500 B.C.) therefore corresponds with the lowest density of houses despite a slight increase around 2000 B.C. Meanwhile, in sharp contrast to house density, the probability density of outdoor features increases starting around 3400 B.C. and maintains a high density until 1500 B.C. Outdoor features and dwellings suddenly almost disappear at the start of the Bronze Age, c. 1500 B.C.

\section{DISCUSSION}

The temporal variation of settlements during the Korean Neolithic can be summarized as follows. Large settlements first appeared in central-western Korea during the Early phase, around the early fourth millennium B.C., probably along with millet cultivation within a broad-spectrum subsistence economy. During the Middle phase, settlements expanded southward to the Geum River valley and southern Korea, as 


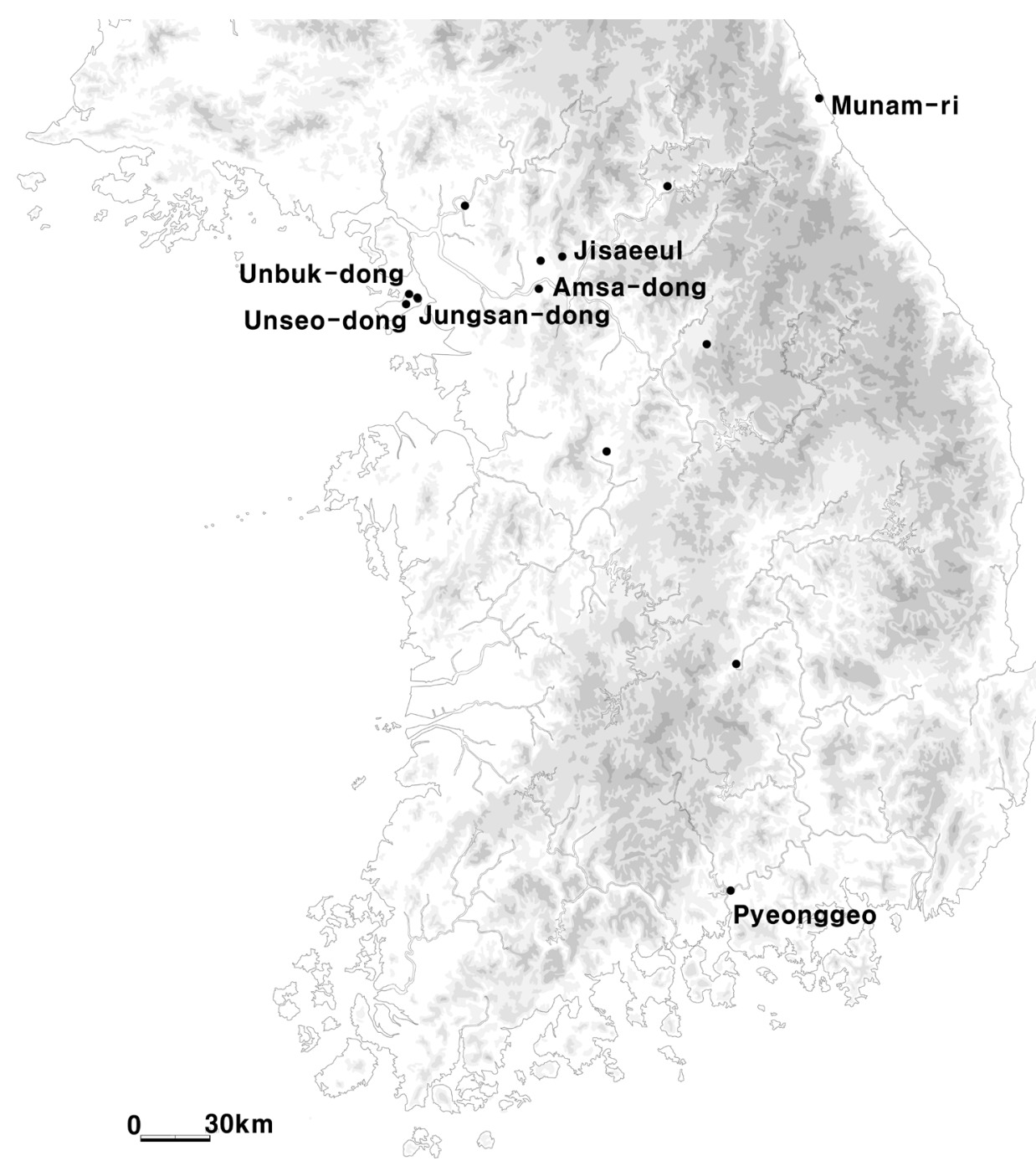

Fig. 7. Distribution of settlements dated 4000-3300 uncal в.P.

well as eastward to the central-eastern coast. The numbers of dwellings and settlements are highest in this phase and various data supporting millet cultivation have also been reported. Shin, Rhee, and Aikens (2012:85-86) describe this phase of the Middle Neolithic as a period of "Chulmun expansion" and "community segmentation."

During the Late phase, the total number of houses in central-western and southern Korea drops to half the numbers recorded in the previous phase. Settlements disappear from the Chungcheong provinces. Houses only increased on the islands in centralwestern Korea. The Final phase witnessed a rapid disappearance of settlements and an increase in outdoor features. Shin, Rhee, and Aikens (2012) propose that horticulture expanded during their Late Neolithic period between 2500 and 1300 cal B.C. (corresponding to our Final phase). However, most sites interpreted as evidence of village settlements or increasing agricultural activities are dated to our Late phase, not the 

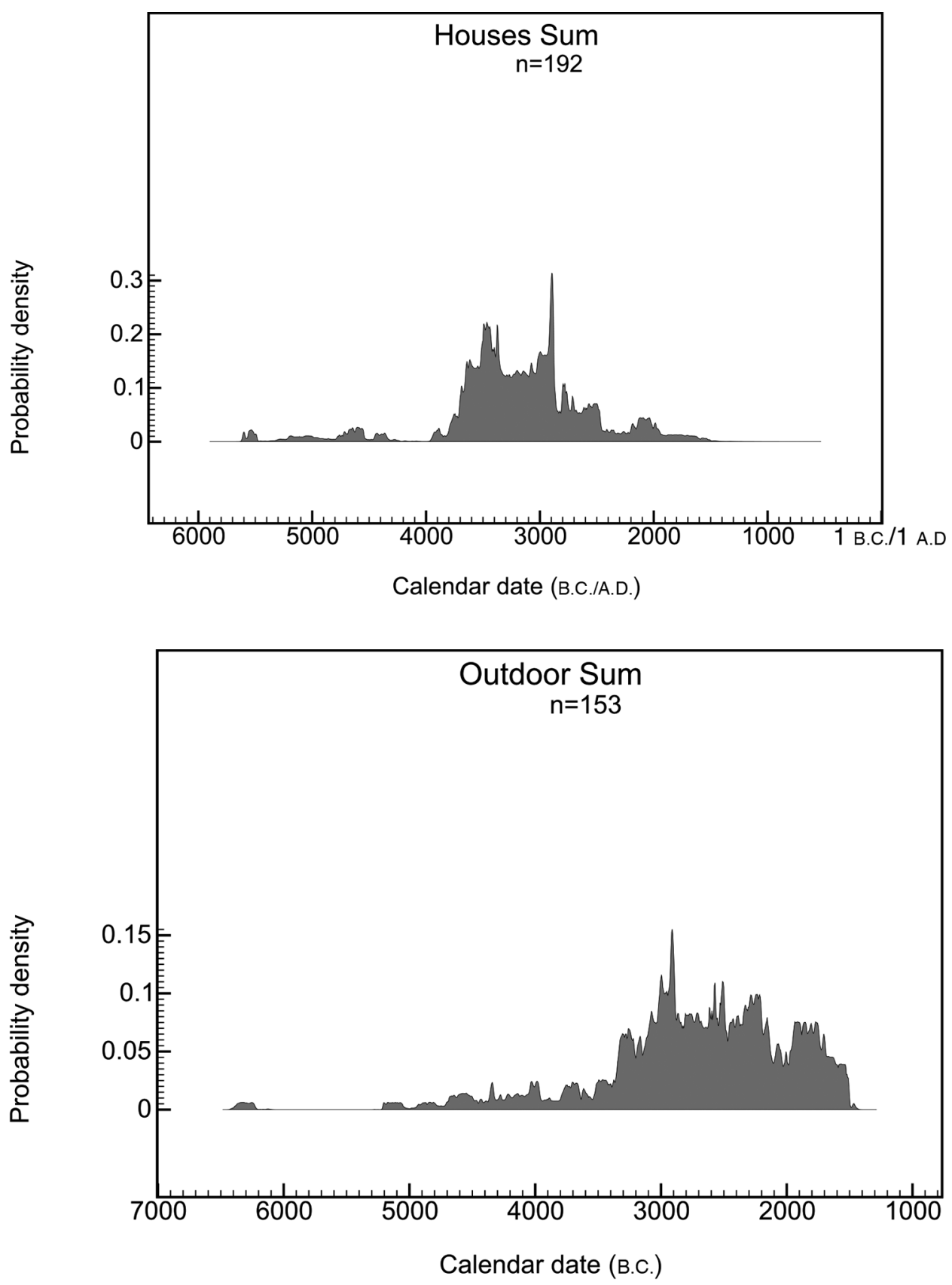

Fig. 8. Summed probability distribution of combined cal B.c. dates from houses (top) and outdoor features (bottom) in Neolithic Korea, using OxCal v4.2 (Bronk Ramsey 2009).

Final phase. Radiocarbon dates from houses and outdoor features show similar temporal variations in sedentism. On the basis of these results, we now discuss some issues regarding sedentism, population density, agriculture, and the transition from the Neolithic to the Bronze Age. 

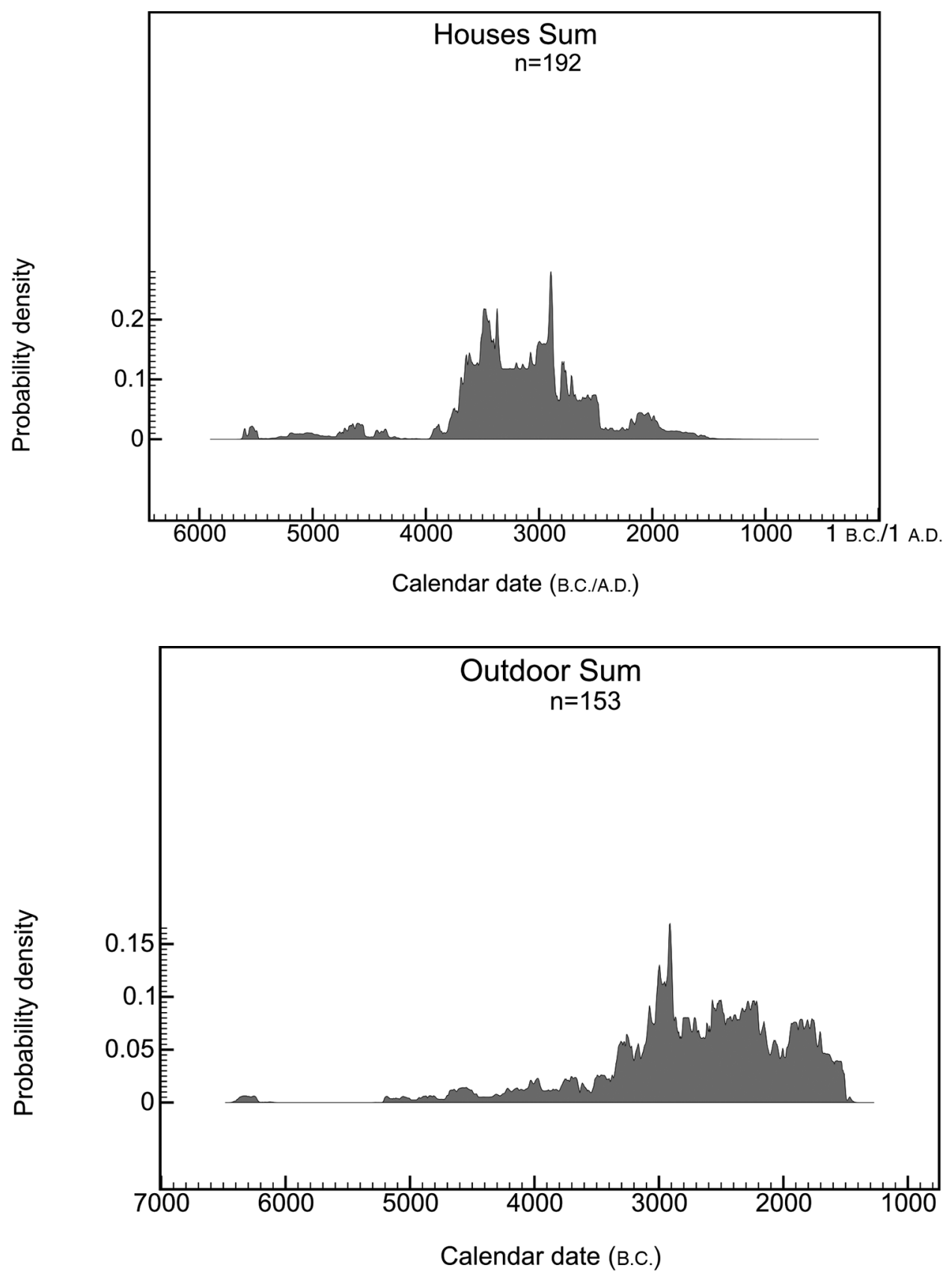

Fig. 9. Summed probability distribution for latest cal B.C. dates from houses (top) and outdoor features (bottom) in Neolithic Korea, using OxCal v4.2 (Bronk Ramsey 2009).

\section{The Appearance of Sedentary Settlements and Millet Cultivation}

The earliest evidence of domesticated plant remains in southern Korea is ambiguous. This includes millet impressions on pottery from Initial and Early Neolithic sites dating to the fifth and early fourth millennium B.C. Such evidence is not firm enough to 
support the existence of widespread millet cultivation or sedentary settlement. Settlements with firm evidence of millet cultivation only appeared in the area during the Middle phase, probably as a consequence of influences from central-western Korea, where sedentary settlements and millet cultivation appeared as early as the early fourth millennium B.C. Despite the fact that actual millet remains have not yet been reported from the Middle phase of central-western Korea, Early Neolithic finds of millet in northwestern (Hwanghae Province of North Korea) and southern Korea, as well as evidence of cultural affinity between northwestern and central-western Korea during the Early Neolithic, strongly suggest that sedentary settlements and millet cultivation occurred coincidentally, as was the case in the Liaoxi region of northern China (Ahn 2006; Zhao 2011).

After settlements with millet cultivation appeared in the early fourth millennium B.C. in central-western Korea, the population increased rapidly until c. 3500 cal B.C. After that, settlements spread to other areas, including the Geum River valleys and the central-east coast. Hunter-gatherers in southern Korea also adopted sedentary lifeways along with millet cultivation. Given this archaeologically documented trajectory, an important question remains: Why did the hunter-gatherers in central-western and southern Korea adopt sedentary lifestyles and start cultivating millet during the fourth millennium B.C.?

$\operatorname{Lim}(2006,2009)$ proposes that small-scale cultivation was adopted to supplement the existing broad-spectrum subsistence economy in order to deal with increased resource stress caused by long-term environmental change and population increase accelerated by long-distance migration (intended to minimize competition over land). Using climatic proxies from Japan and northeastern China, Miyamoto (2009) argues that a cooling event from 3300 B.C. all over northeast Asia was the main cause for the spread of millet cultivation into Korea and the Russian Far East. In contrast, Lee (2011) argues that there is little evidence that people were deprived of resources because of cooling conditions from 3500 to 2000 B.C. She argues that the adoption of domesticates provided complex foragers with the opportunity to expand storable foods and thus increase the stability of their food supply. We note, however, that sedentary hunter-gatherers do not always start cultivating crops even after they have already been exploiting a wide range of plant resources (including nuts) or are preadapted to using plant resources. More importantly, her argument does not explain the simultaneous appearance of sedentary settlements and millet cultivation and their wide spread throughout the region. Furthermore, many lines of evidence support the existence of climatic change during this period: the early fourth millennium B.C. was the ending period of climatic optimum and the late fourth millennium B.C. witnessed a cold/dry climate at a global scale.

Oxygen isotope records from Dongge Cave in southern China show that the Holocene was punctuated by several weak Asian Monsoon (AM) events (centered at 4.4, 5.5, 6.3, 7.2, and 8.3 kycal B.P.), each lasting for 100-500 years (Wang et al. 2005). Following the weak Asian Monsoon event of 5500 cal B.P. at Dongge Cave, which corresponded with the North Atlantic Bond Event 5 at $5900 \mathrm{cal}$ B.P. (Bond et al. 1997), a cold, dry climate began around 3500-3300 B.C., which is when millet cultivation spread across the Korean Peninsula. Climatic change during the fourth millennium B.C. is also identified in Korea. A rapid decrease in oak forest has been documented from many places in western Korea (Jun et al. 2010; Park 2011). Organic geochemical and palynological records from the Yeongsan River estuarine-filled sediment demonstrate both the warmest temperatures c. 5200 uncal B.P. and rapid 
climatic cooling after 4500 uncal B.P. (Nahm et al. 2004). Pollen diagrams from Cheollipo in the central-west coastal region also show a rapid increase in Pinus and simultaneous decrease in Quercus pollen from 4600 uncal B.P. (Park and Yi 2008).

The acorn was the most important plant food for Neolithic populations in Korea. Acorn storage pits appear in the Initial Neolithic. The most abundant and frequently recovered plant food remains from Neolithic sites are acorns, regardless of the existence of millet cultivation. Carbonized woods or charcoals recovered from Neolithic sites are mostly oak (Ahn 2012b). If the climate became dry or cold over a long period, productivity of acorns would have been reduced; eventually pine trees replaced the oak trees. A decline in nut-bearing trees, especially oaks, brought about a shortage of starchy foods for consumption by Chulmun hunter-gatherers as well as wild animals such as wild boars and deer. Thus, Chulmun hunter-gatherers also likely experienced a shortage of wild game. Declining acorn productivity, as well as a retreat of the warm ocean current that provided abundant fish, could have been the main factors that favored the adoption of millet cultivation by Chulmun hunter-gatherers. Fuller and Qin (2010) similarly demonstrate that regional declines in nut-bearing trees, especially oaks, were one of the factors that favored increasing reliance on rice in the lower Yangtze region. To summarize, we suggest long-term, regional scale climatic deterioration followed by an imbalance between the population and resources as the primary cause for changes in subsistence strategies and settlement patterns (Ahn 2011).

While we have focused largely on environmental changes and consequent forager investment in a more predictable resource base through adopting agriculture, some archaeologists examining agricultural origins on a worldwide scale have emphasized the significance of food production for reinforcing growing social stratification and centralized social control through surplus concentration and feasting (Clark and Blake 1994; Hayden 2003). We consider this a very interesting theoretical approach that is important to future research on the origin of food production, but do not take it into account here because there is very little evidence for the emergence of local elites, increasing social stratification, and intensive rituals before or after the adoption of millet cultivation in the Korean Neolithic (Ahn 2005). Surplus production for communal feasts and growing socio-ideological control are only evident after the appearance of rice farming in the Bronze Age (Grier and Kim 2012; Kim 2014).

\section{Decline of Sedentism}

The number of settlements decreased sharply and almost disappeared starting in the late third millennium B.c., while outdoor features (i.e., open-air hearths, shell middens) increased. These trends indicate either a return to nonsedentary, high mobility subsistence practices or a radical population decrease. During the Final Neolithic of the late third and second millennium B.C., shell middens increased again along the coast and on islands. In areas inland, double-mouth rim pottery dated to the Late phase has been reported from many places, but most of these sites consist of artifact scatters around open hearths and rock shelters, presenting little evidence for sedentism.

This means that the earlier expansion of sedentism was replaced by a general lack of sedentism for about a thousand years until the beginning of the Bronze Age. Although we are aware that farmers can be mobile (Graham 1994), plant cultivation usually relates to sedentism. Therefore, the decline of sedentism during the Late and 
Final Neolithic phases may have been connected to dwindling use of cultivation as an economic strategy. This reversal toward less sedentism shows that transitioning from hunting and gathering to farming was a tactical choice that depended on circumstances, rather than a unidirectional and irreversible change (Redding 1988). Arguments for a prolonged transition from the Neolithic to the Bronze Age should be critiqued. Although cultivation and settlements did not totally disappear during the Final Neolithic, the data show that Bronze Age agriculture could not have been the result of a gradual and steadily progressive increase in dependence on crops throughout the Neolithic. Archaeological evidence also does not support Norton's (2000, 2007) model that suggests that population increase was the prime motivation for the adoption of rice agriculture.

We must still ask why the large permanent settlements of the earlier phases were dismantled during the Final phase. We believe environmental change was also the prime mover for this change. Stalagmite records from central China (Dong et al. 2010) as well as Dongge Cave (mentioned above) demonstrate the abrupt lowering of Asian Monsoon intensity c. 4400-4300 cal B.P. over several decades, just before the sudden aridification and cooling of Bond event 3 at $4200 \mathrm{cal}$ B.P. The cooling event is also documented in Japan (at 4300 cal B.P.) and northern China (Miyamoto 2009). Although there is no direct evidence for this climatic fluctuation occurring in Korea, this cooling event is assumed to be a worldwide phenomenon (deMenocal 2001), so it is unlikely Korea was an exception.

Climatic deterioration could have forced Neolithic inhabitants to abandon millet cultivation as well as sedentism. Even though millets are usually resistant to aridity, long-lasting aridity and cooling would have been difficult to overcome. Acorns and wild game would also have been greatly reduced by climatic deterioration. When resources become insufficient, hunter-gatherers tend to adopt new subsistence strategies such as food storage, diversified resource bases, increased mobility or emigration, and food production (Redding 1988). Inhabitants of these areas of Korea during the Final Neolithic may have altered their hunting and gathering strategies by extending catchment areas or increasing their mobility, which would correspond to Redding's $K$ selection strategy (Redding 1988).

\section{Transition to the Bronze Age and Radiocarbon Data}

Both settlement decline and increased mobility during the Final Neolithic could explain the rapid, abrupt transition from the Neolithic to a Bronze Age heavily reliant on rice farming. Paying attention to discontinuities in not only subsistence strategy but also overall material culture, Kim $(2002,2003$, 2006) sees the transition from the Final Neolithic economy of primarily nonsedentary hunter-gatherer pursuits to the Bronze Age agricultural economy in Korea as an abrupt shift in which the millet cultivation of earlier phases of the Neolithic had little influence. By analyzing pottery distribution, he suggests that the hunter-gatherer economy during the Final phase of the Neolithic was based on extensive logistical mobility and resource patches were shared by various groups with no territoriality (Kim 2002, 2006). As territorial migrant farmers appeared in the area and exclusively occupied resource patches that had previously been accessed by the Neolithic hunter-gatherers, the number of resource patches available dramatically decreased. Consequently, the difficulty in maintaining a hunter-gatherer economy supported by logistical mobility markedly increased. Under 
these conditions, the hunter-gatherers had to abandon logistical mobility. They were compelled to adopt farming or were rapidly integrated into farming groups. He concludes that the rapid, abrupt abandonment of the hunter-gatherer economy and subsequent transition to an agricultural economy in Korea resulted from land-use conflict between hunter-gatherer mobility and migrant farmer territoriality, rather than an intensification of the Neolithic incipient farming or voluntary adoption of a new subsistence technology (Kim 2003).

Finally, we raise some issues concerning interpreting radiocarbon dates for the Final Neolithic and earliest Bronze Age sites. A series of papers have recently dealt with transitions from the Palaeolithic to the Neolithic and from the Neolithic to the Bronze Age in prehistoric Korea; their arguments are based on radiocarbon dates mainly obtained from the Seoul National University AMS laboratory (Bae et al. 2013; Kim and Bae 2010). Kim and Bae (2010) insist that the Neolithic-Bronze Age transition in Korea started as early as c. 2300 cal B.C. and continued over the course of 800-900 years, making a migration hypothesis to explain the transition to the Bronze Age untenable. Lee (2011) also argues that most Final Neolithic dates overlap with either the Late Neolithic or the Early Bronze Age and do not support Kim's (2003) argument of little overlap of dates between Final Neolithic and Early Bronze Age sites. However, we obtained more than 100 radiocarbon dates of charcoal samples from the Final Neolithic; most dates center around 4000-3300 uncal B.P. Meanwhile, reliable radiocarbon dates for the Bronze Age increase radically after 3100 uncal B.P. The few overlaps between the Neolithic and the Bronze Age mainly occur c. 3500-3000 uncal B.P. Such cases are rare, and do not support the argument of a long overlap between the Neolithic and the Bronze Age.

Kim and Bae (2010) chose the oldest radiocarbon dates for the Early Bronze Age settlement and the youngest dates for the Late Neolithic settlement to support their argument. However, the oldest radiocarbon dates from wood charcoal usually face the old wood problem (Schiffer 1986). In addition to the old wood problem, radiocarbon samples can be derived from old layers before houses or structures were built or postdepositional layers of later periods. Hence archaeologists who try to use radiocarbon dates for chronology should evaluate the specific archaeological contexts of samples for dating from the excavation report. They should also check radiocarbon dates from samples where there is excessive inconsistency with existing chronology. The comparison of radiocarbon dates for seeds and wood charcoal from the Neolithic in Korea reveals that wood charcoal tend to produce older dates than seeds, probably resulting from the old wood problem (Ahn 2012a). Occasionally, dates a few hundred years earlier were reported from charcoals compared to dates determined from seeds. For example, in the case of an Early Bronze Age house uncovered in Gyodong, Gangreung, $3390 \pm 40$ uncal B.P. was obtained from a charcoal sample, but $3040 \pm 60$ uncal B.P. and $2860 \pm 20$ uncal B.P. were obtained from carbonized rice grains (Ahn 2012c:168-169; Shoda 2010). Therefore, the radiocarbon dates presented by Kim and Bae (2010) of Bronze Age sites before 3300 uncal B.P. should be seen as outliers due to probable old wood effects or contamination.

\section{CONCLUSION}

Archaeologists increasingly use radiocarbon frequency distribution as a proxy for investigating ancient human demographic dynamics (Bamforth and Grund 2012; Collard et al. 2010; Shennan 2013). We distinguish the radiocarbon dates from set- 
tlements from those from outdoor features without dwellings in order to avoid overestimating the population. If hunter-gatherers become increasingly mobile, they may conduct more specialized tasks at short-term camps and therefore leave more such outdoor features. Inferences about population growth and decline also should be checked against other sources of data. Hence, we examined temporal variation in the number of settlements and houses using both pottery chronology and radiocarbon dates. Both methods show nearly identical patterns of growth and decline in sedentism in the last stages of the Neolithic Period in Korea.

Sedentary settlements accompanied by millet cultivation appeared in centralwestern Korea during the early fourth millennium B.C. As population increased in the late fourth millennium B.C., people spread to other areas of the Korean Peninsula. The number of both settlements and houses reached a peak in the late fourth millennium B.C. Both then decreased radically starting in the late third millennium B.C., suggesting a return to increased mobility and/or sharp decrease in population. Although detailed and well-dated Holocene palaeoclimate records are still needed in Korea, the collapse of settlement in the Late and Final stages of the Korean Neolithic must have been related to long-term climatic deterioration and widespread cooling and drying events. In this sense, the transition to an agricultural economy and abrupt changes in material culture and settlement patterns at the beginning of the Bronze Age are better explained by the migration of farmers from the north. Archaeological evidence does not support the continuity model, which insists that a gradual intensification of small-scale cultivation of millet in the Neolithic eventually led to the establishment of the Bronze Age agricultural economy.

The Korean Neolithic case illustrates the argument that hunter-gatherers do not necessarily make immediate and irrevocable transitions to becoming farmers, even after adopting crop cultivation to maintain a broad-spectrum subsistence economy. Rather, increased reliance on crops may make them more vulnerable to climatic deterioration than does hunting and gathering alone.

\section{ACKNOWLEDGMENTS}

We thank Junkyu Kim, Hyemin Yang, Jiwon Yang, Seungho Kang, Jiyoung Park, and Ahrum Song for their efforts in collecting radiocarbon dates. This work was supported by the National Research Foundation of Korea Grant funded by the Korean Government (NRF-2013S1A5B6043901).

\section{REFERENCES CITED}

Ahn, Sung-Mo

2005 Review of the Neolithic agriculture in southern Korea. Journal of the Korean Neolithic Society 10:7-25 (in Korean).

2006 Relationship between sedentism and agricultural emergence in East Asia. Journal of the Korean Neolithic Society $11: 25-54$ (in Korean).

2010 The emergence of rice agriculture in Korea: Archaeobotanical perspectives. Archaeological and Anthropological Sciences 2(2):89-98.

2011 Formation and development of Neolithic culture, in Introduction to Korean Neolithic Culture: 61-98. Seoul: Segyeongmunhwasa (Central Institute of Cultural Heritage) (in Korean).

$2012 a$ Current advances in the study on the origin of foxtail and broomcorn millets in East Asia, in Aspects and Development of Korean Neolithic Culture: 161-196. Seoul: Segyeongmunhwasa (Central Institute of Cultural Heritage) (in Korean).

$2012 b$ Exploitation patterns of nuts and nut-yielding trees from Neolithic to Three Kingdoms periods in Korea based on plant remains. Journal of the Honam Archaeological Society 40:5-48 (in Korean). 
2012c Seeds and radiocarbon dating. Journal of the Korean Archaeological Society 83:152-204 (in Korean).

2013 Temporal changes of crop assemblage based on plant remains, in Archaeology of Agriculture: 69-110, 275-302. Seoul: Sahoe Pyeongnon (Korean Archaeological Society) (in Korean).

2014 Comparison of Neolithic subsistence for Initial Chulmun in southern coast of Korea and Kuahuquia-Hemudu culture in lower Yangtze. Journal of the Korean Neolithic Society 27:1-56 (in Korean).

Bae, Kidong, Christopher J. Bae, and J. C. Kim

2013 Reconstructing human subsistence strategies during the Korean Neolithic: Contributions from zooarchaeology, geosciences, and radiocarbon dating. Radiocarbon 55(2-3):13501357.

Bamforth, Douglas B., and Brigid Grund

2012 Radiocarbon calibration curves, summed probability distributions, and early Paleoindian population trends in North America. Journal of Archaeological Science 39:1768-1774.

Bond, G., W. Showers, M. Cheseby, R. Lotti, P. Almasi, P. deMenocal, P. Priore, H. Cullen, I. HaJdAS, G. BONANI

1997 A pervasive millennial-scale cycle in North Atlantic Holocene and Glacial climate. Science $278: 1257-1266$.

Bronk Ramsey, Christopher

2009 Bayesian analysis of radiocarbon dates. Radiocarbon 51(1) : 337-360.

Buchanan, Briggs, Marcus Hamilton, Kevan Edinborough, Michael J. O’Brien, and Mark Collard

2011 A comment on Steele's (2010) “Radiocarbon dates as data: Quantitative strategies for estimating colonization front speeds and event densities." Journal of Archaeological Science $38(9): 2116-2122$.

Busan Museum

2007 Dongsam-dong Shell Middens. Busan: Busan Museum (in Korean).

Choy, Kyungcheol, Deogim An, and Michael P. Richards

2012 Stable isotopic analysis of human and faunal remains from the Incipient Chulmun (Neolithic) shell midden site of Ando Island, Korea. Journal of Archaeological Science 39(7) : 2091-2097.

CiCH (Central Institute of Cultural Heritage)

2010 Yunseo-dong Site I, Incheon. Seoul: CICH (in Korean).

2011 Jungsan-dong Site, Incheon. Seoul: CICH (in Korean).

Clark, John E., and Michael Blake

1994 The power of prestige: Competitive generosity and the emergence of rank socieites in lowland Mesoamerica, in Factional Competition and Political Development in the New World: 17-30, ed. E. Brumfiel and J. Fox. Cambridge: Cambridge University Press.

Collard, Mark, Kevin Edinborough, Stephen Shennan, and Mark G. Thomas

2010 Radiocarbon evidence indicates that migrants introduced farming to Britain. Journal of Archaeological Science 37(4) : 866-870.

deMenocal, Peter B.

2001 Cultural responses to climatic change during the late Holocene. Science 292 (5517):667673.

Dong, Jinguo, Yongjin Wang, Hai Cheng, Ben Hardt, R. Lawrence Edwards, Xinggong Kong, Jiangying Wu, Shitao Chen, Dianbing Lu, Xiuyang Jiang, and Kan Zhao

2010 A high-resolution stalagmite record of the Holocene East Asian monsoon from Mt. Shennongjia, central China. The Holocene 20 : 257-264.

Fuller, Dorian Q., AND Ling QIN

2010 Declining oaks, increasing artistry, and cultivating rice: The environmental and social context of the emergence of farming in the lower Yangtze region. Environmental Archaeology $15: 139-159$.

GCHRC (Giho Cultural Heritage Research Center)

2009 Nongso Site, Yongin. Anseong: GCHRC (in Korean).

Graham, Martha

1994 Mobile Farmers: An Ethnoarchaeological Approach to Settlement Organization among the Rarámuri of Northwestern Mexico. International Monographs in Prehistory. Ann Arbor, MI. 
Grier, Collin, and Jangsuk Kim

2012 Resource control and the development of political economies in small-scale societies: Contrasting prehistoric southwestern Korea and the Coast Salish region of northwestern North America. Journal of Anthropological Research 68:1-34.

$\mathrm{HA}, \mathrm{IN}-\mathrm{SOO}$

2006 A Study of Chulmun Pottery in the Southern Region of the Korean Peninsula. Busan: Doseo Chulplan/Minjok Munhwa (in Korean).

HAYDEN, BRIAN

2003 Were luxury foods the first domesticates? Ethnoarchaeological perspectives from Southeast Asia. World Archaeology 34(3) : 458-469.

HiCH (Hangang Institute of Cultural Heritage)

2012a Unbuk-dong Site, Incheon. Seoul: HICH (in Korean).

$2012 b$ Jungsan-dong Site, Incheon. Seoul: HICH (in Korean).

Jun, Chang Pyo, Sangheon Yi, and Seong Joo Lee

2010 Palynological implication of Holocene vegetation and environment in Pyeongtaek wetland, Korea. Quaternary International $227: 68-74$.

Kelly, Robert L.

1992 Mobility/sedentism: Concepts, archaeological measures, and effects. Annual Review of Anthropology $21: 43-66$.

1995 The Foraging Spectrum. Washington D.C.: Smithonian Institution Press.

KIM, JANGSUK

2002 The Late Neolithic-Early Bronze Age Transition and Cessation of Island Exploration in Central-Western Korea: The Spread of Territoriality into Mobile Hunter-Gatherer Context. Ph.D. diss. Arizona State University, Tempe.

2003 Land-use conflicts and the rate of the transition to agricultural economy: A comparative study of southern Scandinavia and central-western Korea. Journal of Archaeological Method and Theory 19(3): 277-321.

2006 Resource patch sharing among foragers: Lack of territoriality or strategic choice?, in Beyond Affluence Foragers: 168-191, ed. C. Grier, J. Kim, and J. Uchiyama. Oxford: Oxbow.

2010 Opportunistic versus target mode: Prey choice changes in central-western Korean prehistory. Journal of Anthropological Archaeology 29:80-93.

2011 The end of the Neolithic and the appearance of the Bronze Age, in Introduction to the Korean Neolithic: 481-503. Daejeon: CICH (in Korean).

2014 From labour control to surplus appropriation: Landscape changes in the Neolithization of southwestern Korea. Journal of World Prehistory 27:263-275.

Kim, Jong-Chan, And Christopher J. BAe

2010 Radiocarbon dates documenting the Neolithic-Bronze Age transition in Korea. Radiocarbon $52(2-3): 483-492$.

KoO, JA-JiN

2011 The Study of Neolithic Dwellings and Settlements. Seoul: Segyongmunhwasa (in Korean).

2013 A study on the establishment of the Daecheon-ri type dwellings of the Neolithic period. The Journal of Korean Field Archaeology 18:5-24 (in Korean).

LeE, Gyoung-Ah

2003 Changes in Subsistence Systems in Southern Korea from the Chulmun to Mumun Periods: Archaeobotanical Investigation. Ph.D. diss. University of Toronto, Canada.

2011 The transition from foraging to farming in prehistoric Korea. Current Anthropology 52 : S307S329.

2013 Archaeological perspectives on the origins of azuki (Vignaangularis). The Holocene 23 : 453-459.

Lee, Gyoung-Ah, Gary W. Crawford, Li Liu, Yuka Sasaki, and Xuexiang Chen

2011 Archaeological soybean (Glycine max) in East Asia: Does size matter? PLoS ONE 6(11) : e26720.

Lee, Gyoung-Ah, H. Yun, M. Ko, and C. Kim

2011 Plant use in the Nam River valley during the Neolithic period. Journal of the Yeongnam Archaeological Society 56:5-42 (in Korean).

LEE, JUNE-JEONG

2001 From Shellfish Gathering to Agriculture in Prehistoric Korea: The Chulmun to Mumun Transition. Ph.D. diss. University of Wisconsin-Madison.

2006 From fisher-hunter to farmer: Changing socioeconomy during the Chulmun period in southeastern Korea, in Beyond Affluence Foragers: 54-79, ed. C. Grier, J. Kim, and J. Uchiyama. Oxford: Oxbow. 
LiM, SANG-TAEK

2006 A Study of Chulmun Pottery Culture of West-Central Korea. Ph.D. diss. Seoul National University (in Korean).

2009 The adoption process of agriculture and socioeconomic changes during the Chulmun period in the southern Korean Peninsula, in New Approaches in the Study of Prehistoric Agriculture: 144-171, ed. S.-M. Ahn and J.-J. Lee. Seoul: Sahoe Pyeongnon (in Korean).

2012 Synthesis and contemporaneous relationship of relative chronology in Neolithic centralwestern region, in Aspect and Development of Korean Neolithic Culture: 109-131, ed. Central Institute of Cultural Heritage. Seoul: Segyeongmunhwasa (in Korean).

Miyamoto, Kazuo

2009 Searching for the Origin of Agriculture. Tokyo: Yoshiikawabunkan (in Japanese).

Nahm, Wook-Hyun, J.-Y. Kim, D.-Y. Yang, P.-Y. Bong, K. Takayasu, and K.-M. Yu

2004 Organic geochemical and palynological evidence for Holocene climatic fluctuations of the Yeongsan River estuary, southwestern Korea. Journal of the Geological Society of Korea 40(4) : 441-454 (in Korean).

Nakayama, S., eD.

2014 Origin of Grain Agriculture in the Japanese Archipelago and the Korean Peninsula. Fuefuki City: Yamanashi Prefectural Museum (in Japanese).

Norton, Christopher J.

2000 Subsistence change at Konam-ri: Implications of the advent of rice agriculture in Korea. Journal of Anthropological Research 56(3):325-348.

2007 Sedentism, territorial circumscription, and the increased use of plant domesticates across Neolithic-Bronze Age Korea. Asian Perspectives 46(1) : 133-165.

NRich (National Research Institute of Cultural Heritage)

2013 Munam-ri at Goseong. Seoul: NRICH (in Korean).

Obata, Hiroki

2013 Description on the diagnostic characteristics for identification of millet impressions from Dongsamdong shell midden and Bibongri site. Journal of the Korean Neolithic Society 25:105155 (in Korean).

PARK, JeOngJae

2011 Sediment analysis of the Hwajeon site, in Hwajeon Site, Kwangju. Gwangju: Honam Cultural Property Research Institute (in Korean).

PARK, J. H., AND S. YI

2008 Postglacial environments of the Chungnam Province inferred from pollen analysis: With emphasis of change in climate and vegetation together with human impact. Journal of the Palaeontological Society of Korea $24: 55-75$ (in Korean).

Pusan National University Museum

1981 Suga-ri Shell Midden, Kimhae. Busan: Pusan National University Museum (in Korean).

REDDING, RICHARD W.

1988 A general explanation of subsistence change: From hunting and gathering to food production. Journal of Anthropological Archaeology $7: 56-97$.

SAMPLE, L. L.

1974 Tongsamdong: A contribution to Korean Neolithic culture history. Arctic Anthropology 11(2) : 1-126.

Schiffer, Michael B.

1986 Radiocarbon dating and the "old wood" problem: The case of the Hohokam chronology. Journal of Archaeological Science 13(1): 13-30.

Shennan, STEPhen

2013 Demographic continuities and discontinuities in Neolithic Europe: Evidence, methods and implications. Journal of Archaeological Method and Theory 20:300-311.

Shin, Sook-Chung, Song-Nai Rhee, and C. Melvin Aikens

2012 Chulmun Neolithic intensification, complexity, and emerging agriculture in Korea. Asian Perspectives 51(1):68-109.

SHODA, SHIN'yA

2010 Radiocarbon and archaeology in Japan and Korea: What has changed because of the Yayoi dating controversy? Radiocarbon 52:421-427. 
So, SANGYONG

2013a A Study of Subsistence-Settlement System in Neolithic Central-Western Korea. Ph.D. diss. Hanyang University, Ansan (in Korean).

$2013 b$ A study of the Neolithic chronology of central-western Korea through the use of radiocarbon analysis. Journal of the Korean Archaeological Society 89:4-47 (in Korean).

SONG, EUn-SOOK

2009 The spread of millet cultivation in the South Korean Neolithic, in New Approaches in the Study of Prehistoric Agriculture: 172-191, ed. S.-M. Ahn and J.-J. Lee. Seoul: Sahoe Pyeongnon (in Korean).

Wang, Yongjin, Hai Cheng, R. Lawrence Edwards, Yaoqi He, Xinggong Kong, Zhisheng An, Jiangying Wu, Megan J. Kelly, Carolyn A. Dykoski, and Xiangdong Li

2005 The Holocene Asian monsoon: Links to solar changes and North Atlantic climate. Science $308: 854-857$.

YiCP (Yemaek Institute of Cultural Properties)

2008 Cheoltong-ri Site, Goseong. Chuncheon: YICP (in Korean).

YoO, JiIN

2012 A study of the settlements of the Middle and Late Neolithic period in central-western Korea. Journal of the Korean Archaeological Society 85:4-41 (in Korean).

ZhaO, ZhiJuN

2011 New archaeobotanical data for the study of the origins of agriculture in China. Current Anthropology 52(S4): S295-S306.

\section{ABSTRACT}

There are two conflicting models regarding the role of the Neolithic millet cultivation in the appearance of the Bronze Age farming economy in South Korea. The "continuity model" suggests that the emergence of a farming economy was a consequence of increasing sedentism, and that millet cultivation practiced during the Neolithic played a significant role in the transition to the Bronze Age. On the contrary, the "discontinuity model" suggests that the appearance of the Bronze Age farming economy heavily dependent on rice had little to do with previous millet cultivation in the Neolithic and the degree of sedentism during the latest Neolithic was very low. We test these models by looking into a temporal variation of sedentism, by quantitatively analyzing the quantity of pit houses and settlements based on relative chronology and radiocarbon dates. Sedentary settlements with small-scale millet cultivation appeared in the central-western Korea during the early fourth millennium в.с. They increased sharply during the late fourth millennium в.с. and also appeared in central-eastern and southern Korea, but they almost disappeared in central and southern Korea from the late third millennium B.C., suggesting a return to increased mobility and/or sharp decrease in population. Hence a continuity model for the emergence of a farming economy cannot be accepted. We suggest environmental deterioration as a prime mover for both the appearance of millet cultivation during the fourth millennium в.c. and the disappearance of sedentary settlement from the late third millennium B.c. in Korea. KeYwords: Korea, Neolithic, sedentism, settlement, radiocarbon dates, summed probability distribution, small-scale cultivation, transition to agriculture. 